\title{
STATE OF BALANCE OF THE CRYOSPHERE
}

\author{
C. J. van der Veen \\ Byrd Polar Research Center \\ Ohio State University, Columbus
}

Antarctic ice sheet suggest that it is positive, although the error limits allow for a slightly negative balance. There is an urgent need to greatly improve the current estimates and to monitor the ice sheets continuously for changes in volume and extent. A program based on satellite observation techniques, in cooperation with ground-based surveys repeated over long time periods (many years or decades), appears to be most opportune to achieve this.

\section{INTRODUCTION}

Almost 94\% of all water present on the Earth and in its atmosphere is stored in the world's oceans; snow and ice in the cryosphere account for only about $1.5 \%$ of the total. The bulk of the ice can be found in Antarctica; the volume of the ice sheet there is about 10 times that of the Greenland ice sheet and about 160 times as large as the combined volume of mountain glaciers and small ice caps. Although the water volume of the cryosphere is much smaller than that of the world's oceans, small changes in the volume of grounded ice can have dire consequences for global sea level. This becomes more obvious when considering the volume of grounded ice in terms of sea level equivalent as given in Table 1 . It should be stressed that most of the numbers given in this table contain large uncertainties.

Because considerable amounts of the ice in Greenland and Antarctica are below the present-day sea level, a complete melting of these ice sheets would lead to a smaller sea level rise than that corresponding to the total volume of ice stored there. Furthermore, melting of the large floating ice shelves surrounding West Antarctica has no direct effect on sea level, and hence these are not included in Table 1.

Changes in ice volume occur when the mass balance is nonzero. A positive mass balance means that the glacier is growing (expanding); glacier retreat is caused by a negative mass balance. Thus a crucial issue for future sea level changes is the current mass balance of the terrestrial ice masses.

The mass balance of a glacier or ice cap is the difference between the amount of snow and ice accumulating on the glacier and ice loss from melting and iceberg calving.
When considering only part of a glacier, the effect of ice flow, which may either remove or add mass from any location, must also be taken into account. In that case it is appropriate to use the term net mass balance. The ice sheet is said to be in steady state when the net mass balance is zero everywhere.

Accumulation is primarily due to precipitation of snow and, at the lowest elevations, rainfall. Condensation of ice from vapor and wind transport of snow represent, in most cases, only a minor contribution. An exception to this is central Antarctica, where condensation is an appreciable fraction of the accumulation [e.g., Bromwich, 1988]. In the case of floating ice tongues and shelves, basal freezing may be important, but for grounded ice the primary location for accumulation is the surface.

Two important factors that affect the amount of snowfall at the surface are the temperature of the air and the orography. The latter effect results in increased snowfall near the edges of ice sheets and on the upwind side of glacier-covered mountains, where the steep slopes force the moist air to flow upward. Atmospheric temperatures have a large effect on accumulation in that they restrict the maximum snowfall. This limitation occurs because the atmosphere cannot carry unlimited amounts of water vapor; the humidity of the atmosphere depends strongly on the air temperature. This means that, with increasing elevation (decreasing temperature), a critical height is reached, above which snowfall starts to decrease as a result of the reduced moisture-carrying capacity of the atmosphere. So it is not surprising that in the central regions of East Antarctica (with a mean summer temperature of $-30^{\circ} \mathrm{C}$ and a mean winter temperature of $-65^{\circ} \mathrm{C}$ ) [Schlesinger, 1984], snowfall is extremely low, less than $0.05 \mathrm{~m} \mathrm{yr}^{-1}$ [Giovinetto and Bentley, 1985]. 
TABLE 1. Some Data on the Cryosphere

\begin{tabular}{|c|c|c|c|c|}
\hline & $\begin{array}{c}\text { West } \\
\text { Antarctica }\end{array}$ & $\begin{array}{c}\text { East } \\
\text { Antarctica }\end{array}$ & Greenland & $\begin{array}{l}\text { Glaciers and } \\
\text { Small Ice Caps }\end{array}$ \\
\hline Area, $10^{6} \mathrm{~km}^{2}$ & 2.1 & 9.9 & 1.8 & 0.6 \\
\hline Volume, $10^{6} \mathrm{~km}^{3}$ & 3.4 & 25.9 & 3.0 & 0.2 \\
\hline \multicolumn{5}{|l|}{$\begin{array}{l}\text { Average annual } \\
\text { accumulation }\end{array}$} \\
\hline m water/yr & 0.3 & 0.1 & 0.3 & 1.2 \\
\hline Equivalent sea level, m & 9.4 & 71.7 & 8.3 & 0.5 \\
\hline Actual sea level, m & 6.0 & 60.0 & 7.5 & 0.5 \\
\hline $\begin{array}{l}\text { Loss of ice primarily } \\
\text { by ... }\end{array}$ & calving & calving & $\begin{array}{l}\text { calving and } \\
\text { melting }\end{array}$ & melting \\
\hline $\begin{array}{l}\text { Dynamic response time, } \\
\text { year }\end{array}$ & $100-1000$ & $\begin{array}{r}10,000 \\
100,000\end{array}$ & $1000-10,000$ & $10-100$ \\
\hline
\end{tabular}

After Oerlemans [1989].

Melting is one of the processes that removes ice from a glacier. However, it only represents a true loss if the meltwater exits the ice mass instead of percolating downward into the firn where it refreezes.

Another important mechanism by which ice is lost is iceberg production at the ice margin. In Greenland this accounts for about half of the total ice loss. In Antarctica, iceberg production is significant at the seaward edges of the floating ice shelves. It should be noted, however, that this has no consequences for sea level. Once the formerly grounded ice flows across the grounding line and enters the floating ice shelves, it has no further impact on sea level. It may therefore be more relevant to consider only the volume of grounded ice, in which case the important parameter describing the loss of ice is the rate at which ice is flowing from grounded regions into floating ice shelves.

Changes in ice volume are the consequence of an imbalance between net accumulation and ablation. The ice sheet will adjust its pattern of flow to compensate for this imbalance until an equilibrium configuration is reached. This configuration is commonly referred to as the steady state, because the geometry of the glacier, and the associated pattern of flow, will remain constant with time as long as the accumulation and ablation do not change (and other boundary conditions also remain constant).

In nature, ice masses rarely achieve a steady state because the atmospheric boundary conditions, determining to a large extent the accumulation and ablation, are continuously changing. Because ice masses react actively (i.e., by adjusting the pattern of flow) to changing climatic conditions that cause a nonzero mass balance, their response is, in many instances, very complicated. Feedback processes such as the coupling between surface elevation and snowfall or melting, or the glacio-isostatic adjustment of the Earth's crust to a changing ice load, can strongly amplify the glacier's response [cf. Oerlemans and Van der Veen, 1984].

The dynamic response of glaciers to changes in climate can be described by diffusive kinematic wave theory [e.g., Hutter, 1983, chap. 6]. According to this theory, the time scale for adjustment depends strongly on the size of the ice mass under consideration. The response time of the Antarctic ice sheet is of the order of tens of thousands to 100,000 years, whereas the response time of a typical mountain glacier is about 100 years; the response time of the Greenland ice sheet lies somewhere in between these extremes (1000-10,000 years). As a result, a climatic change will have its first impact on mountain glaciers, which are generally believed to be sensitive indicators of climate [e.g., Oerlemans, 1986a]. Conversely, the different components of the cryosphere may still be adjusting to changes in climate that occurred at different times in the past. Whillans [1981] calculates that south Greenland is presently responding to climatic changes that happened during the last 10,000 years, approximately, whereas central East Antarctica is reacting to changes that took place over the past 200,000 years.

The wide range of response times makes it difficult to distinguish between possible causes of observed changes. For example, Reeh and Gundestrup [1985] argue that the present-day thickening of the interior regions of the Greenland ice sheet may in part be the result of downward movement of Holocene ice, slowly thinning the bottom layer of relatively soft Wisconsin ice. (This tends to make the glacier stiffer so that ice velocities become smaller.) On the other hand, Zwally [1989] proposes that this thickening may be indicative of a warmer polar climate, associated with the global warming during the present century. Because recent trends may be developing on long-term changes, additional data (such as past accumulation rates) and long-term monitoring are needed to address the issue of why changes may be occurring.

Whatever the causes may be, the volume of ice stored in the cryosphere is continuously changing. These changes may be dramatic, such as the collapse of the northern hemisphere ice sheets after the last glacial period, or they can be more subdued, as seems to be the case at present. Assessing the current rate of change is fundamental to developing scenarios for sea level change in the (near) future. Unfortunately, very little is known about the current 
state of balance of terrestrial ice. In fact, only a handful of mountain glaciers have been monitored for changes in volume over an extended period of time. For the large ice caps in Greenland and Antarctica the picture is even worse. Spot measurements of snow accumulation, melting, and iceberg production are extrapolated over entire drainage basins, if not the entire ice sheet, to determine the net mass balance. It should come as no surprise that the different estimates encompass a wide range of values so that only qualitative assessments are warranted.

Below is a summary of available observations and mass balance estimates. The division commonly used in glaciology is followed. The cryosphere is partitioned into three parts: the mountain glaciers and small ice caps, the Greenland ice sheet, and the Antarctic ice sheet. The cryosphere has other components as well (permafrost, sea ice, and land snow cover), but their combined water volume is very small compared to that of land-based glaciers, and thus their potential effect on sea level (if any) is negligible.

The major impediment to a more accurate assessment of the mass balance of glaciers and ice sheets is the timeconsuming techniques involved in conventional field programs. The most frequently used techniques are discussed in section 5 to illuminate the difficulties and inherent errors involved and also to stress the need for a comprehensive program aimed at measuring the mass balance of mountain glaciers as well as the polar ice caps. A program that involves satellite observations seems to be most opportune as proven by results of studies discussed in section 6.

\section{MOUNTAIN GLACIERS}

Mountain glaciers and small ice caps in general are active and susceptible to small changes in climate. Evidence for this sensitivity to climate is the widespread advance of mountain glaciers during the Little Ice Age, which started in the thirteenth and fourteenth centuries [Porter, 1986] and culminated between the mid-sixteenth and the mid-nineteenth century [Grove, 1988]. The shift in equilibrium line altitude between the Little Ice Age maxima and the present one is estimated by Porter [1981] to be about 100 to $200 \mathrm{~m}$ for the northern hemisphere mid-latitude glaciers. If this shift can be attributed to changes in the mean atmospheric temperature, and assuming the average lapse rate has remained close to its present value $\left(5-6^{\circ} \mathrm{C} / \mathrm{km}\right)$, the average temperature difference between the present and the Little Ice Age maximum is about $0.5^{\circ}-1.2^{\circ} \mathrm{C}$. In fact, this difference may be closer to the lower limit if snow accumulation was higher during the colder periods when the glaciers advanced, as appears to have been the case in the European Alps [Orombelli and Porter, 1982]. Smith and Budd [1981] argue that the temperature change affecting the glaciers refers most likely to the summer time only. They find that the retreat of four European glaciers can be explained by an increase in the average summer temperature of about $0.5^{\circ}-1.0^{\circ} \mathrm{C}$.

In the European Alps the Medieval Optimum (a period of relatively mild climate) ended around 1300 A.D., and glaciers started advancing. Major advances, which brought the glaciers in the Alps and in northern Scandinavia to their Little Ice Age maximum, started in the second half of the sixteenth century. In southern Scandinavia the major advance did not occur until the latter part of the seventeenth century. In Iceland, evidence of expanding glaciers is lacking until the last decade of the seventeenth century. Although less well documented, glaciers on the North American continent seem to have followed a similar pattern (cf. Grove [1988] for a detailed overview).

Glaciers have receded since about the mid-nineteenth century worldwide. The scale and the widespread nature of this recession are comparable to that of the advance prior to the Little Ice Age maximum. The retreat has not been uninterrupted, however. Small readvances, or slowing of the rate of retreat of the ice fronts, have occurred worldwide in the 1880s and 1920s. In a number of cases the temporary advance can be attributed to increased snowfall and/or lower annual temperatures. It appears, however, that these interruptions were only minor disturbances superimposed on a continuing trend of glacier retreat. More recent trends (since 1960) suggest that a shift from a regime dominated by shrinking and receding glaciers to a more mixed regime has taken place. Whereas in 1960, about $6 \%$ of some 400 glaciers were advancing; this percentage increased to about $55 \%$ in 1980 [Wood, 1988]. Mass balance data are available only for some 50 glaciers, but these indicate a similar mixed pattern. For example, observed glaciers in Austria increased in volume from 1960 to 1980 , while glaciers in Switzerland, the Soviet Union, and Canada (mostly) decreased during this period [Wood, 1988]. Haeberli et al. [1989] observe a similar trend of an increasing number of growing glaciers, most notably on the maritime slopes of mountain ranges.

A number of numerical modeling studies has been undertaken to simulate historic glacier front variations over the last few centuries [Oerlemans, 1986b, 1988; Huybrechts et al., 1989; Stroeven et al., 1989]. When forcing the model with local climate data, simulations are not very successful and, in particular, fail to simulate the retreat observed during the last century. But when a global forcing derived from an energy balance climate model is used, the simulations yield much better results. This suggests that variations in the global radiation balance may be very important and supports the results of Oerlemans [1986a], who found that valley glaciers can be extremely sensitive to changes in the radiation budget. This means that the worldwide retreat of mountain glaciers may, in part, be caused by the increased concentrations of infrared-absorbing gases in the atmosphere.

It should be noted that variations in glacier length are not always proportional to volume changes. For example, 
after surging, the snout of a glacier may have advanced considerably, even though the ice volume has decreased. For this reason, Meier [1984], in his effort to estimate the contribution of small mountain glaciers to rising sea level, considers only 37 northern hemisphere glaciers for which long-term time series of ice volume are available. By extrapolating these data to account for all other unmeasured glaciers, Meier concludes that, for the period 1884 to 1975 A.D., glacier wastage appears to account for one third to one half of the observed rise in sea level, although the error margin is quite large. It may be pointed out that this contribution approximately equals the fraction of the observed sea level rise that is not explained by thermal expansion of the oceans.

The average rate of eustatic sea level rise between 1900 and 1961 attributed by Meier [1984] to melting glaciers and small ice caps is $0.46 \pm 0.26 \mathrm{~mm} \mathrm{yr}^{-1}$. More than a third of this contribution derives from the mountains bordering the Gulf of Alaska. Other appreciable contributions are from the high mountains in Central Asia and the Patagonian Andes [Meier, 1985].

Oerlemans [1989] tries to quantify the net contribution of mountain glaciers to changing sea level by basing a schematic model on the following assumptions: (1) the equilibrium ice volume decreases exponentially with temperature; (2) the rate of glacier wastage is proportional to the remaining ice volume relative to the equilibrium volume and to the temperature perturbation; and (3) the response time of all mountain glaciers can be characterized by a single number. Under these assumptions the change in ice volume stored in mountain glaciers and small ice caps is given by the following equation:

$$
\frac{d V}{d t}=-\alpha\left(T-T_{R}\right)\left[V-V_{R} \exp \left\{-\left(T-T_{R}\right) / \beta\right\}\right] .
$$

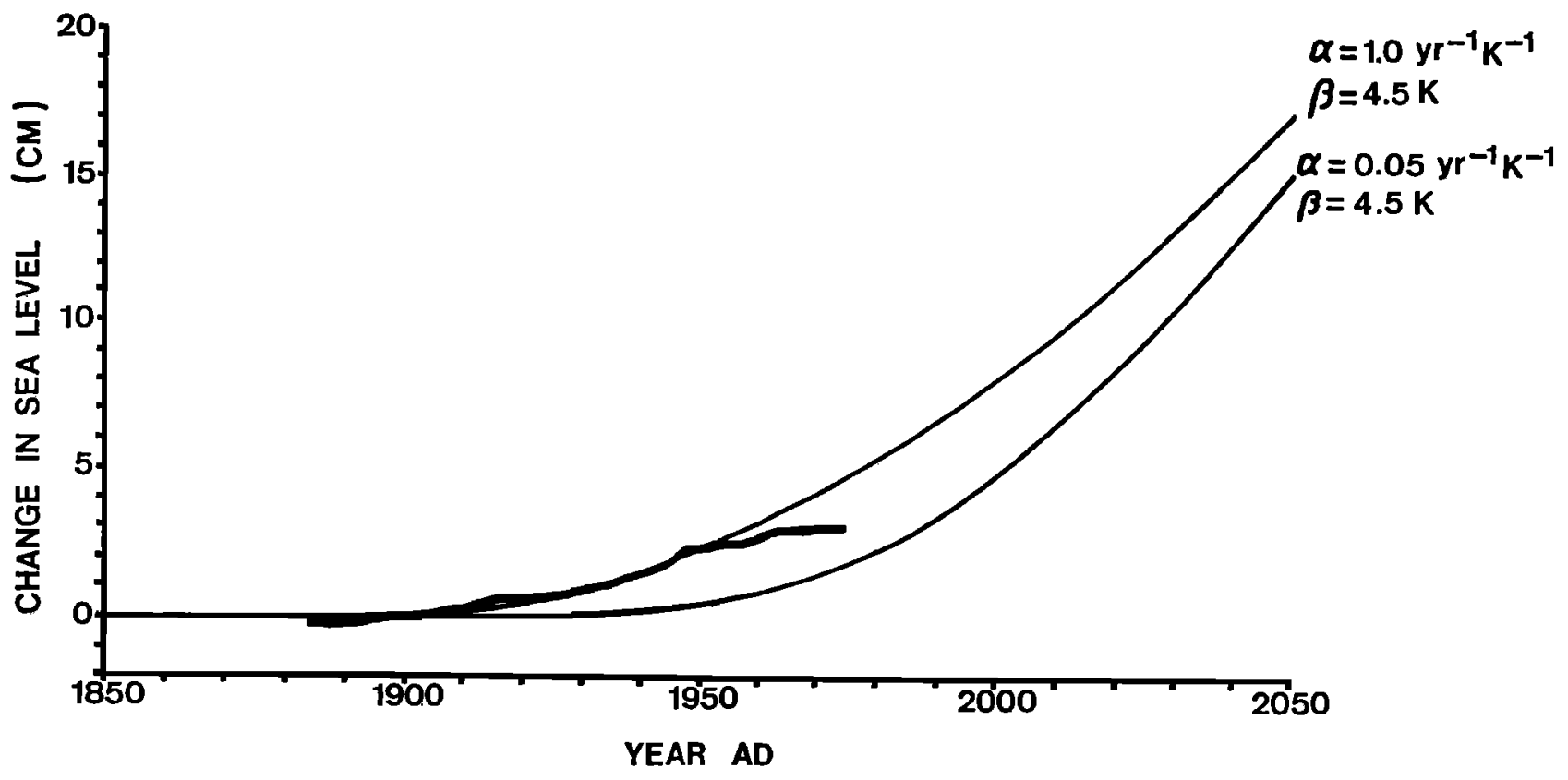

Here $V$ represents ice volume, expressed in meters sea level equivalent. The initial state (1850 A.D.) is defined by the initial ice volume, $V_{R}=0.45 \mathrm{~m}$ sea level equivalent, and the initial global mean surface temperature $T_{R^{\circ}} T$ represents the actual temperature, for which Oerlemans uses (with $t$ the time in years A.D.),

$$
T-T_{R}=\eta(t-1850)^{3},
$$

based on the results of the Villach II discussion [Jaeger, 1988].

Figure 1 shows the contribution of mountain glaciers to sea level as calculated from the simple model for the period 1850-2050 ( $\alpha=0.05 \mathrm{yr}^{-1} \mathrm{~K}^{-1}, \beta=4.5 \mathrm{~K}$ ) [following Oerlemans, 1989]. At the end of this period the rise in temperature is $2.16 \mathrm{~K}$. Comparing this curve with that from Meier [1984] shows poor agreement between the model and observations. By using $\alpha=1.0 \mathrm{yr}^{-1} \mathrm{~K}^{-1}$, agreement improves considerably, at least for the period up to about 1950 A.D. The subsequent deceleration in glacier retreat is not simulated by the simple model. This is mainly because the curves shown in Figure 1 strongly reflect the cubic increase in temperature.

\section{THE GREENLAND ICE SHEET}

\subsection{The Interior}

Few direct observations of the changes of surface elevation in Greenland are available. Bauer et al. [1968] compare measurements over the period 1948-1959 along a 40-km stretch of the Expédition Glaciologique Internationale au Groenland (EGIG) transect (Figure 2), covering the main part of the ablation zone on the western

Figure 1. Estimate of the contribution of mountain glaciers and small ice caps to rising sea level (relative to the 1900 stand), based on the simple model of Oerlemans [1989]. The heavy curve, extending from 1884 to 1975 , is the estimate of glacier melt from Meier [1984]. 


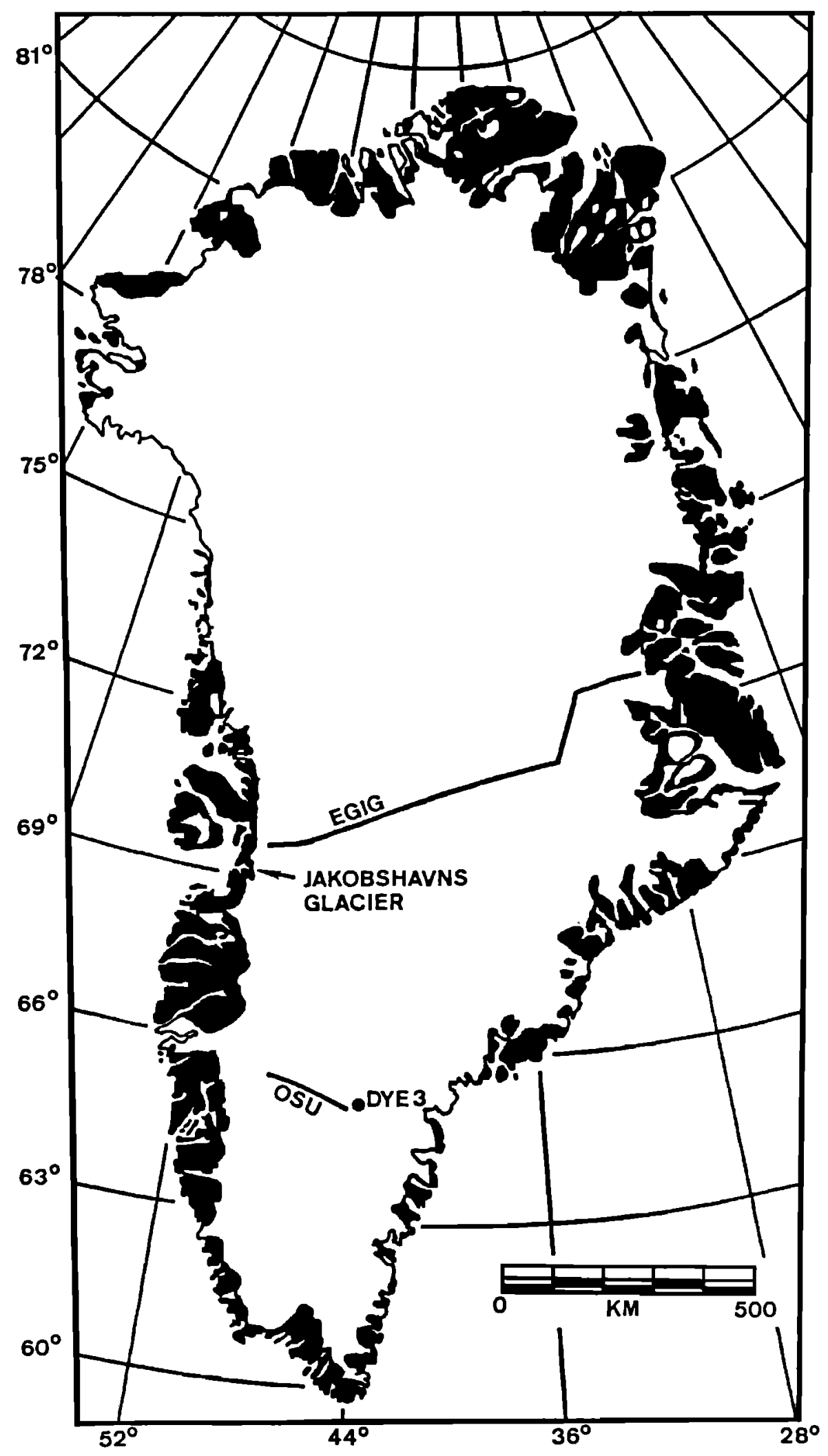

Figure 2. Location map for Greenland. 


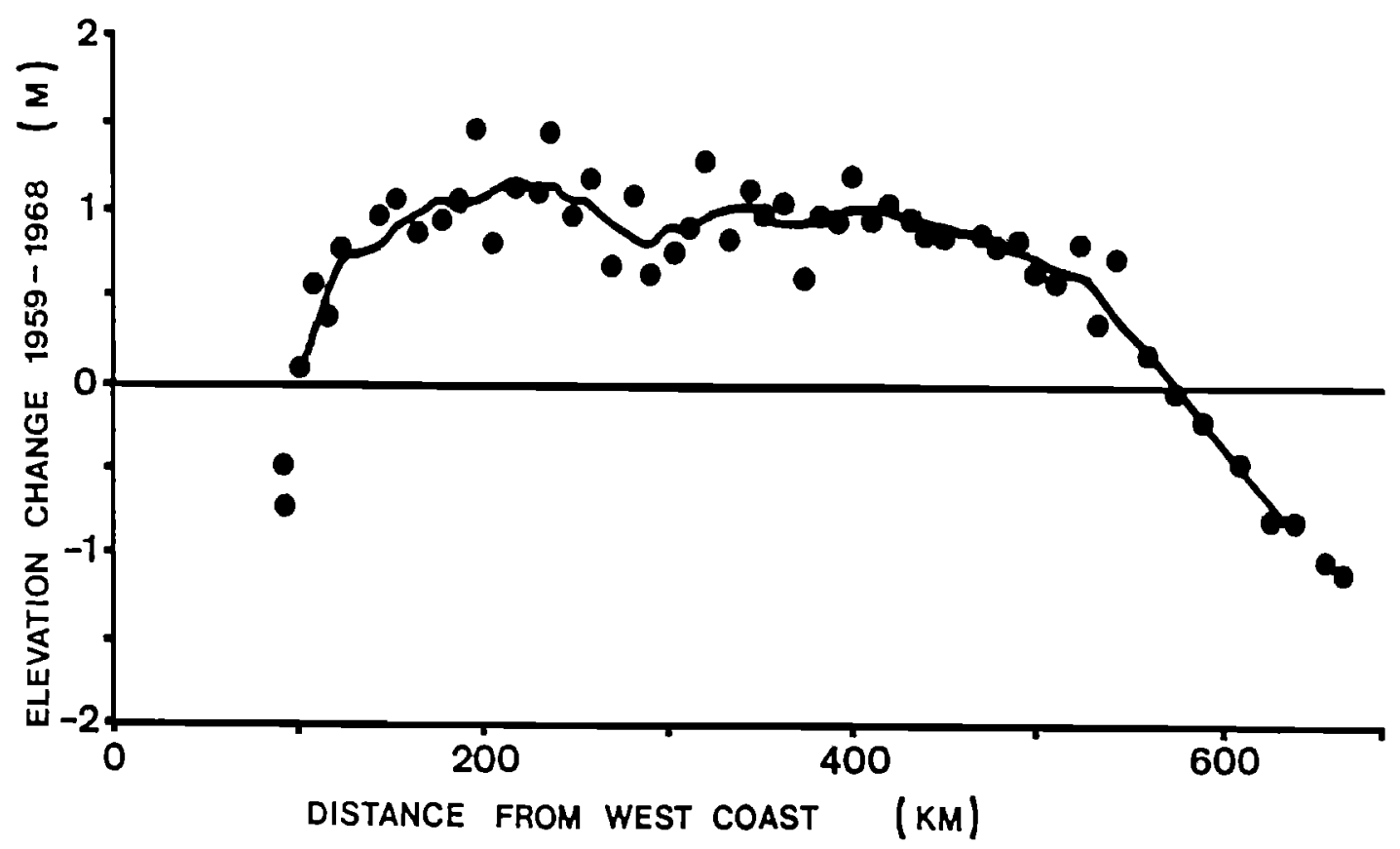

Figure 3. Observed surface elevation change of the Greenland ice sheet between 1959 and 1968 along the EGIG line [from Seckel, 1977]. (Reproduced by courtesy of the Commission for Scientific Research in Greenland.)

margin of the ice sheet. They find a lowering of the ice surface of about $0.33 \mathrm{~m} \mathrm{yr}^{-1}$. Because the survey markers used for marking the survey sites move along a rough surface, extrapolation of the altitudes measured in 1959 to those of the corresponding positions in previous years is an important source of uncertainty.

The measurements of Seckel [1977] for the period 1959-1968 cover the entire EGIG profile across the ice sheet. In the ablation zone the surface appears to be falling at a rate of about $0.25 \mathrm{~m} \mathrm{yr}^{-1}$. In the accumulation zone the ice sheet is thickening at an average rate of about $0.085 \mathrm{~m}$ $\mathrm{yr}^{-1}$, except for the east-facing slope, where the observations indicate a decrease of the surface elevation of a few centimeters per year (Figure 3).

More recently, Zwally et al. [1989] analyzed satellite radar-altimeter data and concluded that the surface elevation south of $72^{\circ} \mathrm{N}$ is increasing. Comparing measurements from the Geosat (1985) and Seasat (1978) radar altimeters, the observed spatially averaged rate of thickening is about $0.233 \pm 0.030 \mathrm{~m} \mathrm{yr}^{-1}$. These results suggest a much higher rate of thickening than do the measurements made along the EGIG line. Furthermore, whereas both Bauer et al. [1968] and Seckel [1977] find a lowering of the ice surface in the ablation zone, Zwally et al. [1989] infer a thickening in the marginal zones above the 700-m elevation contour as well (their measurements do not include the coastal part of the ice sheet where the ice surface is less than $700 \mathrm{~m}$, presumably because there the slope-induced error becomes too large). It is not clear how these differences can be explained.
Reeh and Gundestrup [1985] estimate the mass balance of the ice sheet in the Dye 3 area from observed ice thickness, accumulation rates, surface velocities, and surface strain rates. By considering the divergence of the ice flux they calculate that the surface elevation is increasing at a rate of $0.03 \pm 0.06 \mathrm{~m} \mathrm{yr}^{-1}$. This is considerably less than the $1 \mathrm{~m} \mathrm{yr}^{-1}$ increase calculated by Mellor [1968], who uses the same technique as Reeh and Gundestrup [1985]. However, this large value is based on the application of unrealistically large values of surface velocity and transverse strain rate.

Kostecka and Whillans [1988] use a numerical flow line model to compute the mass balance along the Ohio State University (OSU) and EGIG transects. Measured surface velocities are compared with velocities calculated from up-glacial accumulation rates, ice thicknesses, and flow line spreading. Their results indicate a positive mass balance corresponding to a thickening of $0.06 \pm 0.08 \mathrm{~m}$ $\mathrm{yr}^{-1}$ along the OSU transect and near-equilibrium conditions $\left(0.0 \pm 0.07 \mathrm{~m} \mathrm{yr}^{-1}\right)$ along the EGIG line.

Bindschadler [1984] uses a similar comparison between the balance flux at the terminus and the actual ice flux to estimate the mass balance of the drainage basin feeding the Jakobshavns Glacier. His results suggest that this basin is in equilibrium or slightly thickening. Kostecka and Whillans [1988] argue that this may be explained by the accumulation rate values used by Bindschadler [1984]. These were determined by interpretation of layering observed in shallow pits and tend to be larger than the 30-year averages obtained from ice cores. 


\subsection{Outlet Glaciers}

An extensive overview of glacier fluctuations in Greenland is presented by Weidick [1968]. Most (geological) information is available for west Greenland. Many of the glaciers draining the inland ice have been retreating since the middle of the nineteenth century. As is the case for most European mountain glaciers, this retreat was interrupted by periods of readvance, or halt of the recession, around 1890 and 1920 . More recent data suggest that for the northernmost lobes of the inland ice a new readvance may have started around 1960 . During the readvance around 1890, many glacier lobes reached their maximum extent of the Little Ice Age. The readvance of 1920 was, in general, of a lesser extent.

Local glaciers in west Greenland (i.e., those not draining the inland ice) reached their Little Ice Age maximum before the nineteenth century and possibly as early as 1750. Most of the local glaciers remained close to this maximum position up to the mid-nineteenth century when retreat set in. Between 1860 and 1880 there was a general readvance of the ice fronts, albeit of less magnitude than earlier advances. Recession of the glaciers followed, with the highest rate of retreat occurring between 1920 and 1940. Since 1940 the rate of recession has decreased for most of the local glaciers. Again, the general retreat was interrupted by short and minor readvances, between 1915 and the $1920 \mathrm{~s}$, which were in many cases only sufficient to stabilize the ice front.

From east Greenland, little information is available. The maximum extent of the glaciers there occurred in the middle of the eighteenth and nineteenth centuries, although a later readvance around 1890 seems to have brought many ice fronts close to their Little Ice Age maximum reached during previous advances. Several investigators have reported that many glaciers in east Greenland have retreated strongly during this century [cf. Weidick, 1968].

\subsection{Mass Balance of the Entire Ice Sheet}

The change in ice volume $V$ is the difference between the annual snow accumulation $A$ and the annual loss of ice by melting $M$ and iceberg calving $C$ :

$$
\frac{d V}{d t}=A-M-C
$$

Many authors have attempted to estimate each of the terms on the right-hand side, but large uncertainties still exist [cf. Reeh, 1985]. Table 2 gives some of the mass balance estimates available in the literature. These estimates suggest that the Greenland ice sheet is not greatly out of balance, although an accurate assessment of the present transfer of mass between the ice sheet and the oceans is not possible.

\section{THE ANTARCTIC ICE SHEET}

\subsection{Large-Scale Studies}

Estimates of the mass balance of entire drainage basins (shown in Figure 4) are in most cases based on a few scattered observations and involve large margins of error. Uncertainties arise because accumulation rate measurements are usually available along a traverse extending inland from the coast. Furthermore, proper delineation of a particular drainage basin hinges on the availability of accurate surface topography maps. In fact, some of the studies mentioned below do not consider drainage basins, but geometrically regular areas. This obviously introduces another source of error, namely the estimate of the amount of ice entering the region under consideration through the inland boundaries. For this reason, the following discussion of results from large-scale mass balance studies is a rather qualitative summary of the present state of knowledge.

Lorius [1962] gives a synthesis of glaciological investigations conducted in Terre Adélie, mainly during the International Geophysical Year. The mass balance for a sector whose outer edge is the coast between $135^{\circ} \mathrm{E}$ and $142^{\circ} \mathrm{E}$ appears to be positive, corresponding to a thickening of about $0.1 \mathrm{~m} \mathrm{yr}^{-1}$. This is in contrast with visual observations of the ice front near the Dumont d'Urville base, which show a retreat. The difference may be explained because certain ablation processes could have been underestimated and because the calculations are based on only a few scattered surface measurements. Another possibility suggested by Lorius [1962] is that the coastal retreat may be the response to climate changes in the past.

TABLE 2. Estimates of the Mass Balance of the Greenland Ice Sheet

\begin{tabular}{lclll}
\hline & Accumulation & \multicolumn{1}{c}{ Ablation } & \multicolumn{1}{c}{ Calving } & Total \\
\hline Loewe [1936] & +425 & -295 & -150 & -20 \\
Bauer [1955] & +446 & -315 & -215 & -84 \\
Bader [1961] & +630 & -120 to -270 & -215 & +145 to +295 \\
Benson [1962] & +500 & -272 & -215 & +13 \\
Bauer [1966] & $+500 \pm 250$ & $-330 \pm 165$ & $-280 \pm 140$ & $-110 \pm 555$ \\
Weidick [1985] & $+500 \pm 100$ & $-295 \pm 100$ & $-205 \pm 60$ & $0 \pm 260$ \\
& & & & \\
\hline
\end{tabular}

Expressed in $\mathrm{km}^{3}$ water equivalent per year. 


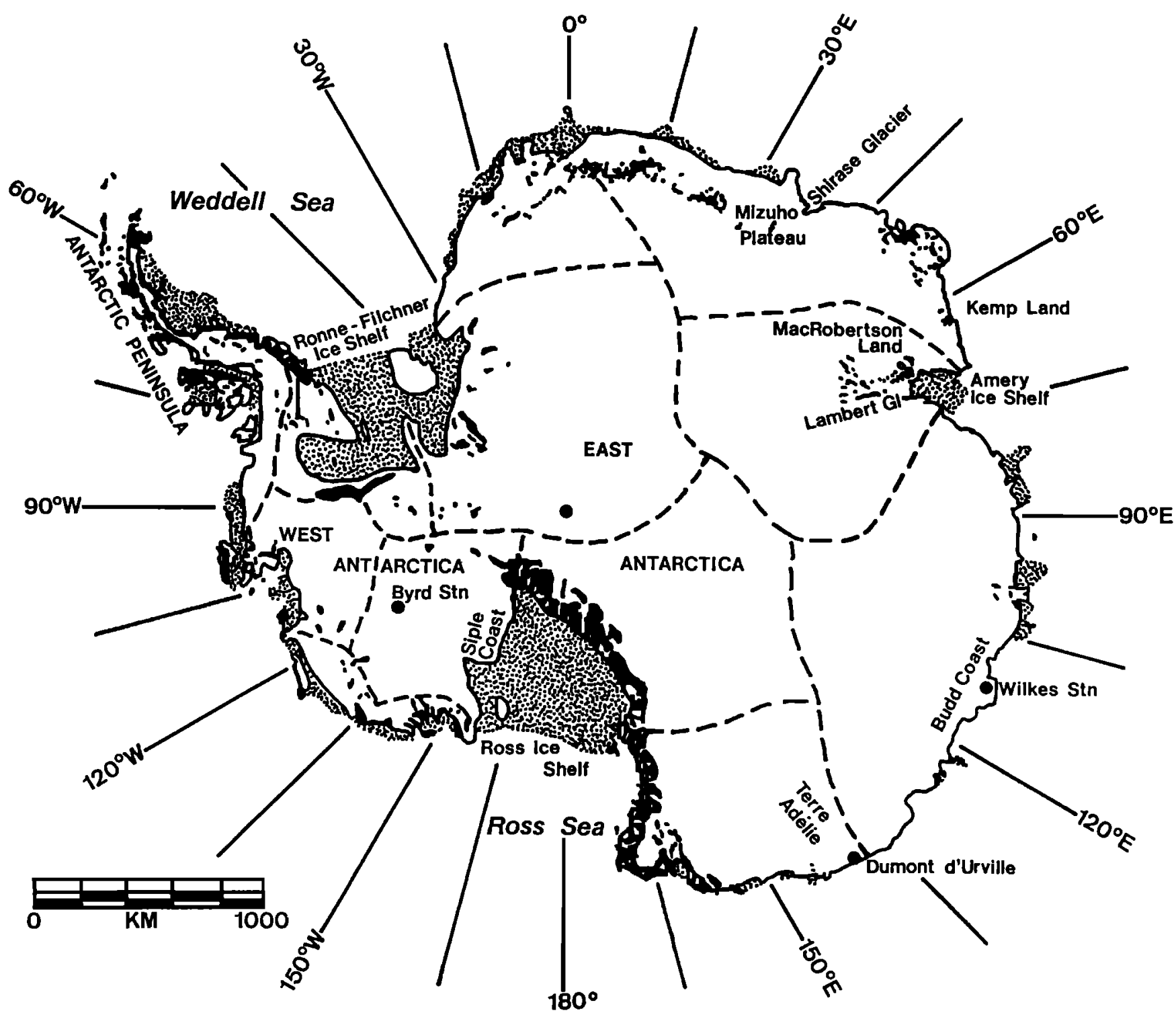

Figure 4. Location map for Antarctica. Dashed lines indicate the boundaries of the major drainage basins.

Cameron [1964] discusses the mass balance of the ice sheet in the Budd Coast area near Wilkes station and concludes that the ice sheet is thinning there. However, he considers a rectangular area, rather than a natural drainage basin, so there may be an important error in the estimate of ice mass flowing into the region. Cameron [1964] argues that the mass balance in this area is mainly dependent on local snow accumulation and entirely neglects the contribution of inland ice flow into this area. His arguments, however, are not very convincing, and his conclusion about the state of balance of the ice sheet in this region may be challenged.

The drainage basin feeding the Amery Ice Shelf through the Lambert Glacier has been studied extensively by the Australians. Budd et al. [1967] conclude that the mass balance of this drainage system is positive. Supply of ice mass is about three times as large as the loss of ice at the front, suggesting an average thickening of $4 \mathrm{~cm} \mathrm{yr}^{-1}$. An updated assessment by Allison [1979] basically gives the same results.

Local studies in the coastal area of MacRobertson and Kemp Lands also suggest a positive balance. Mellor [1959] considers the coastal region between $45^{\circ} \mathrm{E}$ and $80^{\circ} \mathrm{E}$ and finds a surplus of accumulation over losses, although he feels that the available data are insufficient to claim that the ice sheet is growing. Morgan and Jacka [1981] use measurements made along a traverse route in MacRobertson and Kemp Lands to calculate the ice flux across the traverse route (approximately parallel to the coast, following the 2000 -m elevation contour). Comparison with the calculated mass input from snow accumulation in the basin inland of the traverse shows that the net mass input is almost twice as large as the mass outflow. 
Naruse [1979] interprets the results of two surveys (1969 and 1973/1974) along a 250-km-long triangulation chain in the inland region of the Mizuho Plateau (approximately following the $72^{\circ} \mathrm{S}$ parallel). Results indicate a large thinning of the ice sheet at a rate of about $0.7 \mathrm{~m} \mathrm{yr}^{-1}$. This need not be representative for the entire plateau, however. Shimizu et al. [1978] estimate a rather large positive budget for the entire drainage basin feeding the Shirase Glacier. It is thus very well possible that the observed thinning in the interior is local, or of very recent occurrence.

A review of available measurements in the Antarctic Peninsula and the Weddell Sea region is given by Doake [1985]. He concludes that there is no definitive evidence of significant changes in mass balance there. Whatever few data are available suggest a net mass loss, but no quantitative estimates are warranted.

The two drainage basins discharging into the Ross Ice Shelf appear to have a positive mass balance [Giovinetto et al., 1966; Giovinetto and Zumberge, 1967]. An updated estimate by Bentley [1985] indicates that inflow from East Antarctica into the eastern part of the Ross Ice Shelf exceeds the outflow at the ice front. In contrast, the western part of the ice shelf is in, or close to, a steady state. The drainage system of the West Antarctic ice sheet flowing into the Ross Ice Shelf appears to be gaining mass at present.

\subsection{Local Studies}

Apart from the study of Naruse [1979] on the central Mizuho Plateau, very few local studies have been undertaken. The region upstream of Byrd Station (West Antarctica) has been studied by Whillans [1973, 1976, 1977]. On a more regional scale the Siple Coast area has been investigated in detail by various groups of U.S. scientists.

Upstream of the Byrd Station borehole, a strain grid was deployed in 1963-1964 and resurveyed in 1964-1965 and again in 1967-1968. The grid extends over $163 \mathrm{~km}$ from the ice divide to the borehole site. Along the grid, relative ice movement can be calculated from the repeat surveys, while net surface mass balances were obtained from changes in pole heights over periods of up to 8 years. Whillans [1973] uses these data to calculate the mean volume flux along the grid and compares these with the current rate of surface accumulation upstream of points along the grid. He concludes that near the ice divide the ice sheet seems to be in equilibrium. Farther downstream, however, the volume flux is larger than that required for equilibrium by as much as $15 \%$ near Byrd Station. Although some differences may be caused by the traverse not following the ice flow exactly, or by complex flow at depth, it seems most likely that the calculated difference between actual and balance flux is due to ice sheet thinning. A similar, but more careful, analysis is presented by Whillans [1977]. Again, calculations indicate that the region is thinning slowly $\left(0.03 \mathrm{~m} \mathrm{yr}^{-1}\right)$, but it is still close to a steady state. This confirms the results of Whillans [1976] based on analysis of radio echo determined layering in the ice sheet. These data suggest that the ice sheet near Byrd Station is close to steady state. However, small deviations from equilibrium as calculated by Whillans $[1973,1977]$ would not be detectable by this technique.

The Siple Coast is characterized by a number of fast-flowing ice streams (labeled alphabetically, see Figure 5) draining into the Ross Ice Shelf, and separated by virtually stagnant interstream ridges. So far, ice streams B and $C$ have been studied extensively. Of these two, ice stream $\mathrm{C}$ is anomalous in that it has all characteristics of an active ice stream, except that velocities are very low (about $\left.1 \mathrm{~m} \mathrm{yr}^{-1}\right)$ [McDonald and Whillans, 1988]. This suggests that this ice stream has recently stopped and is currently thickening at its accumulation rate $\left(0.12 \pm 0.02 \mathrm{~m} \mathrm{yr}^{-1}\right)$ [Shabtaie et al., 1988]. Ice stream $\mathrm{A}$ is discharging more ice than is being accumulated in the catchment area and is currently thinning at a rate of 0.08 with a standard deviation of $0.03 \mathrm{~m} \mathrm{yr}^{-1}$ [Shabtaie et al., 1988]. Similarly, the mass balance of ice stream B shows a deficit corresponding to a thinning rate of $0.06 \pm 0.04 \mathrm{~m} \mathrm{yr}^{-1}$ [Whillans and Bindschadler, 1988]. It may be noted that this rate is significantly smaller than earlier estimates, mainly as a result of better constraints on the boundaries of the catchment area. According to Shabtaie et al., [1988], the pattern of thickness change along ice stream $B$ is rather complex (Figure 6). There appears to be a slight thinning in the catchment area, a large thinning of the two tributaries B1 $\left(1.26 \pm 0.37 \mathrm{~m} \mathrm{yr}^{-1}\right)$ and B2 $(0.57 \pm 0.23 \mathrm{~m}$ $\mathrm{yr}^{-1}$ ) and a thickening in the main body of the ice stream. It is not clear what causes this complex behavior, although it suggests a transient response to either a change in internal dynamics, or an adjustment to a change in external forcings. At the mouth of ice stream B the Crary Ice Rise complex is thickening at an average rate of $0.14 \pm 0.09 \mathrm{~m}$ $\mathrm{yr}^{-1}$ [MacAyeal et al., 1987], which may be caused by the imbalance of ice streams A and B. Bindschadler et al. [1989a] calculate the regional pattern of thickness change in the vicinity of Crary Ice Rise and find significant rates of thickening upstream of the ice rise and important thinning downstream, assuming zero basal melting or freezing. The net mass balance of the entire area is near zero, but the regional differences cannot represent a redistribution of mass already within the region considered, because the region of mass gain is upstream of the region of mass loss. Rather, these results suggest that the ice rise is migrating in the direction of the grounding line.

\subsection{Mass Balance of the Entire Ice Sheet}

Estimating the state of balance of the entire Antarctic ice sheet is hampered by a lack of accumulation rate data over large parts of the interior. Because surface ablation is negligible, ice loss is achieved through calving at the ice fronts and through basal melting under the peripheral floating ice shelves. Although basal melting is believed to occur in extensive areas under the grounded portion of the 


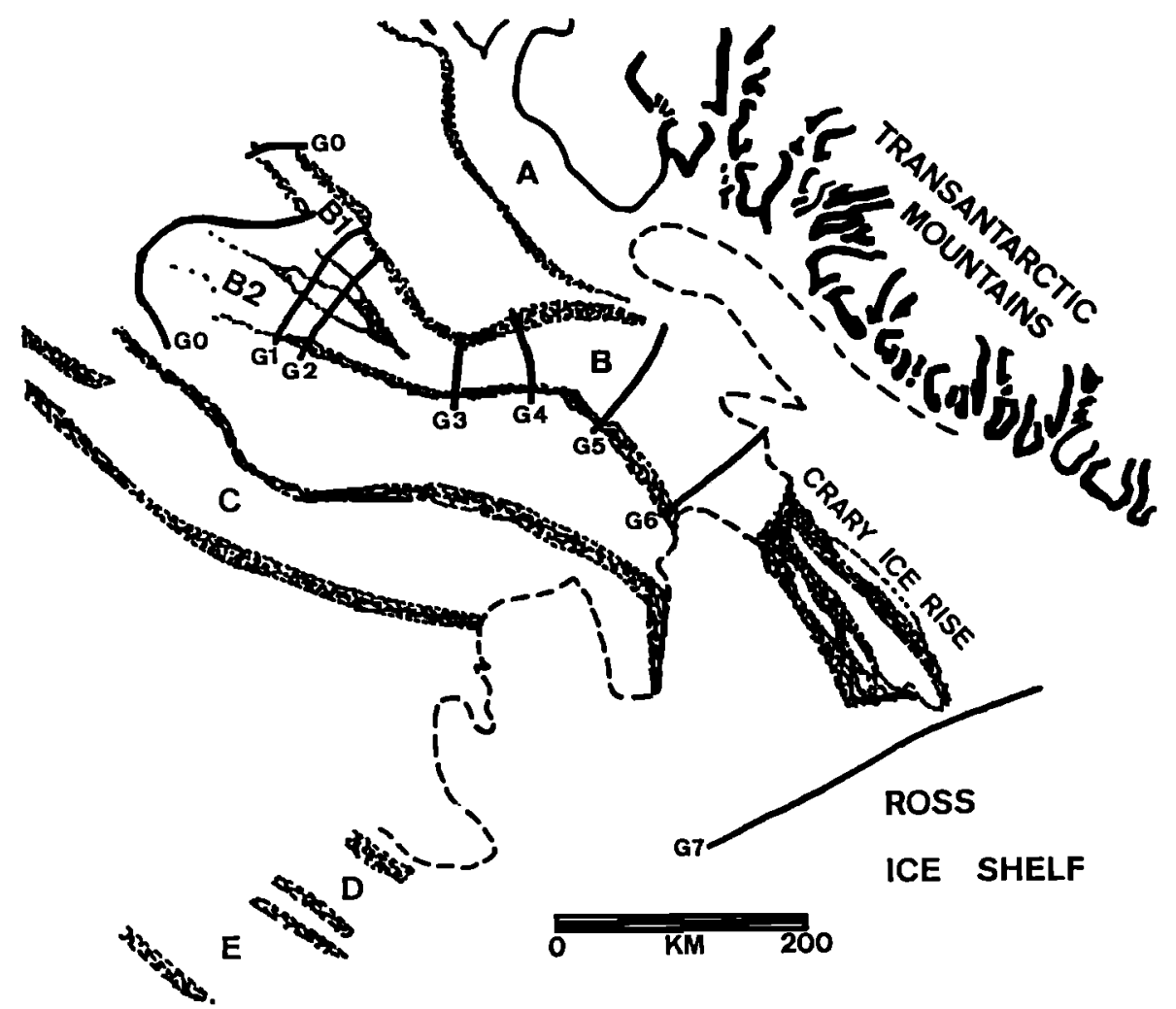

Figure 5. Map of the Siple Coast, West Antarctica. Heavy lines correspond to the gates across ice stream B through which ice fluxes are calculated by Shabtaie et al. [1988]; the dashed line indicates the grounding line (after Shabtaie et al. [1988, Figure 3]; reporduced by courtesy of the International Glaciological Society and the authors.)

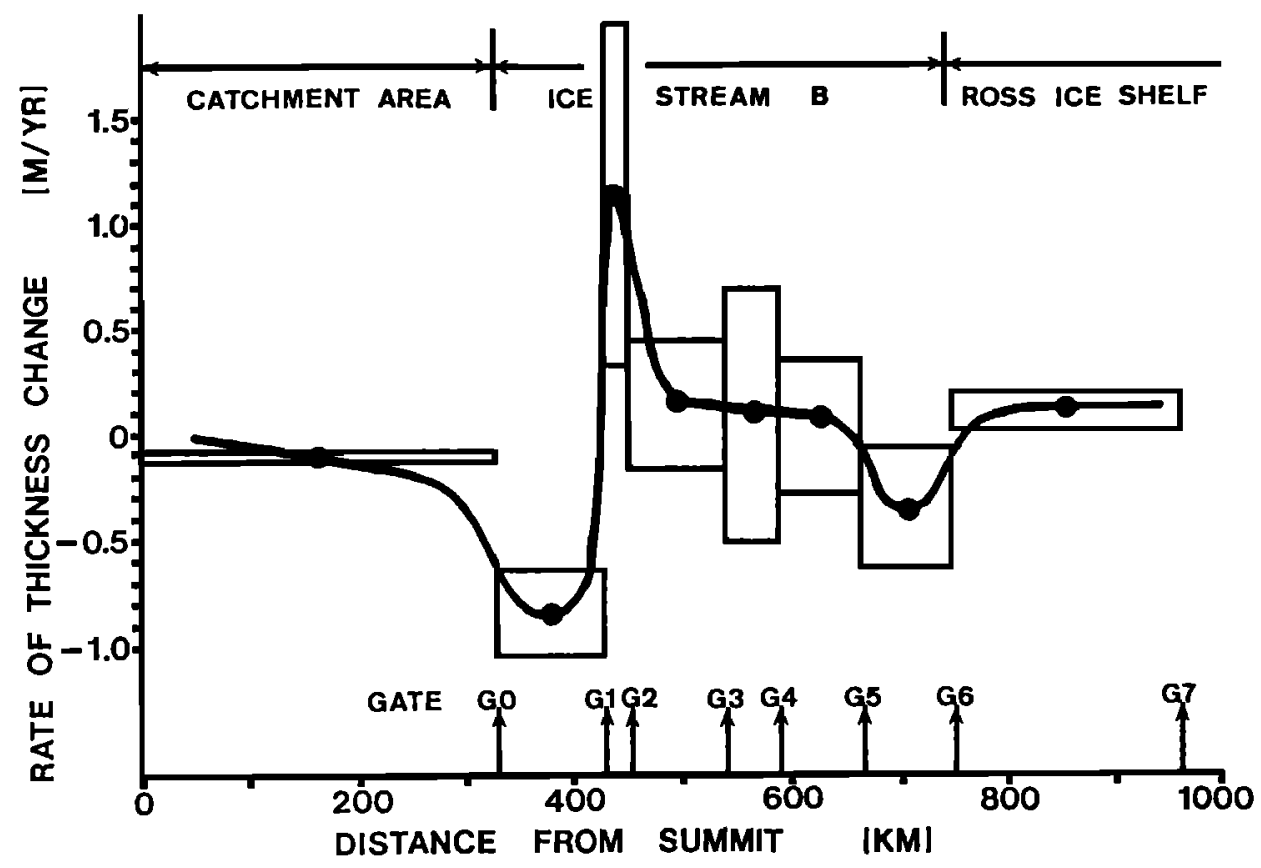

Figure 6. Mean rate of thickness change $(\dot{H})$ versus distance along ice stream $\mathbf{B}$. The measured values of $\dot{H}$ for each flow band block are plotted at the center of the blocks between the successive gates shown in Figure 5 . The height of the boxes represents the error estimate of $\dot{H}$ for each block. (From Shabtaie et al. [1988]; reproduced by courtesy of the International Glaciological Society and the authors.) 
ice sheet, this probably has a minor effect on the net mass budget.

Table 3 gives a summary of mass balance estimates, compiled by Meier [1983]. These estimates suggest that the mass balance of the entire ice sheet is positive, although the error limits allow for a slightly negative balance. This concurs with the conclusion of Budd and Smith [1985], who computed balance velocities over the entire ice sheet and compared these with measured velocities. This comparison suggests that the total surface accumulation is nearly balanced by the outflow of ice at the margins, with a discrepancy most likely in the range of 0 to $20 \%$. The corresponding lowering of global sea level is about 0 to $1.2 \mathrm{~mm} \mathrm{yr}^{-1}$.

\section{CONVENTIONAL GLACIER MEASUREMENT TECHNIQUES}

\subsection{Accumulation}

Short-term accumulation rates (yearly averages or mean values over a few years) can be obtained from pole height measurements. This requires placing survey stakes (for example, bamboo poles or steel conduits) vertically in the firn and measuring the exposed lengths of the poles repeatedly. From these lengths, surface mass balances can be calculated, taking into account the depth variation of firn density and settling of the firm and poles.

Yearly values of accumulation can also be derived from snow pit studies. This requires digging a pit and locating the previous summer's surface. In many instances this surface is marked by a layer of dirt or by a sudden change in density. For example, on the Hintereisferner in Austria, Hoinkes [1957] finds that the typical distribution of density with depth, as found in the winter snow cover, shows a minimum at the bottom and a maximum somewhere in the middle of an annual layer. Because this profile is preserved for many years, it can be used to detect boundaries between annual layers. By combining thicknesses of these layers with profiles of density, annual values of accumulation rates can be calculated.

Average accumulation rates since the mid-1950s and mid-1960s can be derived from gross beta activity profiles of hand-augered cores. Depending on the local accumulation rates, these cores have to be about 8 to $30 \mathrm{~m}$ long, in order to reach the 1954 depth. Samples (10-15 cm long) from the cores are melted, and the radioactive isotopes are concentrated on ion exchange filters. The radioactivity of these filters is measured to identify the 1954-1955 and 1964-1965 horizons, which are characterized by an increased level of radioactivity (resulting from nuclear tests conducted in the atmosphere). Figure 7 shows an example of a radioactivity profile measured in a core retrieved from West Antarctica. The depths of the highlevel samples are calculated from the drilling records, allowing for core loss (only in very rare cases is core recovery $100 \%$ ) as described by Whillans and Bolzan [1988]. Taking into account the variation in density with depth, the average accumulation rates since 1954-1955 or 1964-1965 can be calculated [cf. Whillans and Bindschadler, 1988].

Long-term accumulation rates can be derived from deep ice cores. Annual layers have to be identified and transferred into accumulation rate records. Again, corrections have to be made for density variations as well as for variations in accumulation rates upstream of the borehole site. Some modeling of the local ice flow is required to calculate the total vertical strain since the time of deposition. Figure 8 shows a record thus obtained and allows determination of secular trends, as well as short-term

TABLE 3. Estimates of the Mass Balance of the Antarctic Ice Sheet

\begin{tabular}{llllll}
\hline & Accumulation & $\begin{array}{c}\text { Ablation on } \\
\text { Ice Sheet }\end{array}$ & $\begin{array}{l}\text { Melting Under } \\
\text { Ice Shelves }\end{array}$ & Calving & Total \\
\hline Kosack [1956] & +1650 & $-2050^{*}$ & $0 \dagger$ & -550 & -950 \\
Loewe [1956] & +1200 & 0 & 0 & -140 to & +1100 to \\
& & & -1300 & -40 & $0 \neq$ \\
Wexler [1958] & +1340 & $0 \dagger$ & -48 & -570 & +1055 \\
Mellor [1959] & +1747 & -74 & -675 & -270 & +826 \\
Lister [1959] & +1906 & -135 & -220 & -660 & $0 \ddagger$ \\
Wexler [1961] & +880 & $0 \dagger$ & -120 & -1210 & $+1320 \S$ \\
Kotlyakov [1962] & +2650 & 0 & -163 to -323 & -1276 & $0 \ddagger$ \\
Rubin [1962] & +1439 to & 0 to -74 & & & \\
& +1673 & & -200 & -1450 & +240 \\
Loewe [1967] & +1900 & -10 & & & \\
\hline
\end{tabular}

Excluding the Antarctic Peninsula, in general, expressed in $\mathrm{km}^{3}$ water equivalent per year (compiled by Meier [1983]).

* May include evaporation in accumulation area.

†Assumed.

†Zero net balance assumed.

\$Assumed 50\% imbalance. 


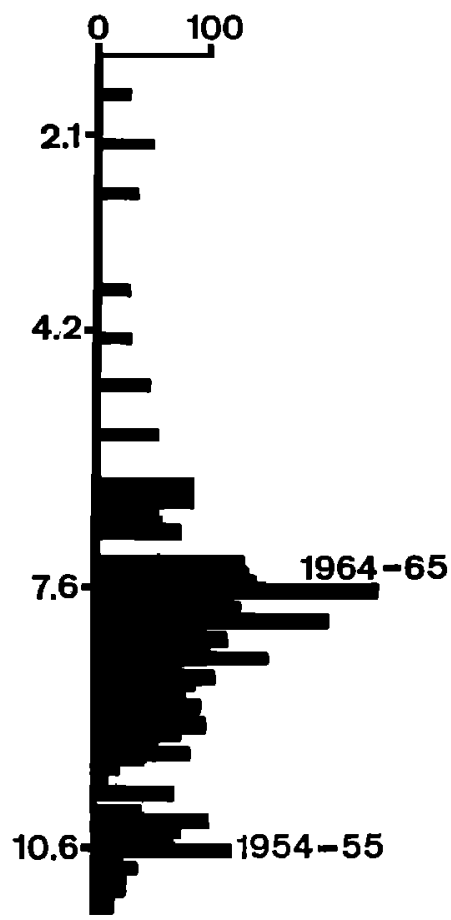

Figure 7. Gross beta profile for a West Antarctic station. Vertical axis is linear in the sample number, with selected depths indicated. Horizontal bars indicate measured counts for those samples measured.

fluctuations [cf. Reeh et al., 1978]. One should be careful in interpreting such records, however. As shown by Reeh et al. [1985], the low-frequency variation of the Dye 3 record reflects upstream short-distance variations in accumulation rate, rather than temporal fluctuations.

\subsection{Ablation}

Measurements of ablation are in general more complicated than those of accumulation, not in the least because the ablation zone of a glacier is, in many instances, less easily accessible than the accumulation area. There does not appear to be a practical method of determining long-term ablation rates. Only seasonal or short-term averages can be measured using ablation stakes. As for accumulation rates, the exposed lengths of the stakes are measured repeatedly but with a coirection made for vertical movement of the stake due to ice flow [Nye, 1968; Vallon, 1968]. A major problem is to eliminate the effect of settlement in the upper firn layers. Combined with the generally complex microrelief of the ice surface, this makes the usual technique of measuring surface lowering on stakes difficult to interpret, and calculated ablation rates are often inaccurate.

The straight-edge method is often used to eliminate the influence of melt hollows around the stake on the measurements. The distance from the top of the stake to a straight ruler (0.5-1 m, say) placed flat on the surface is measured [Müller and Keeler, 1969; Braithwaite and Oleson, 1984]. Although this method allows determination of an average ice level around the stake and thus reduces errors caused by the small ablation hollows, the readings are not necessarily a true representation of the lowering of the ice surface. This is because the rate of lowering of the peaks in the microrelief (on which the straight ruler rests) may differ from that of the total surface. Müller and Keeler [1969] estimate that the error thus introduced is about \pm 0.5 $\mathrm{cm}$. It may be noted that similar considerations play a role when measuring accumulation from pole heights. However, accumulation measurements are usually made at 1-year intervals, whereas ablation measurements are often carried out through one melt season, with only a few days between successive measurements. Thus the error is relatively larger for the ablation measurements.

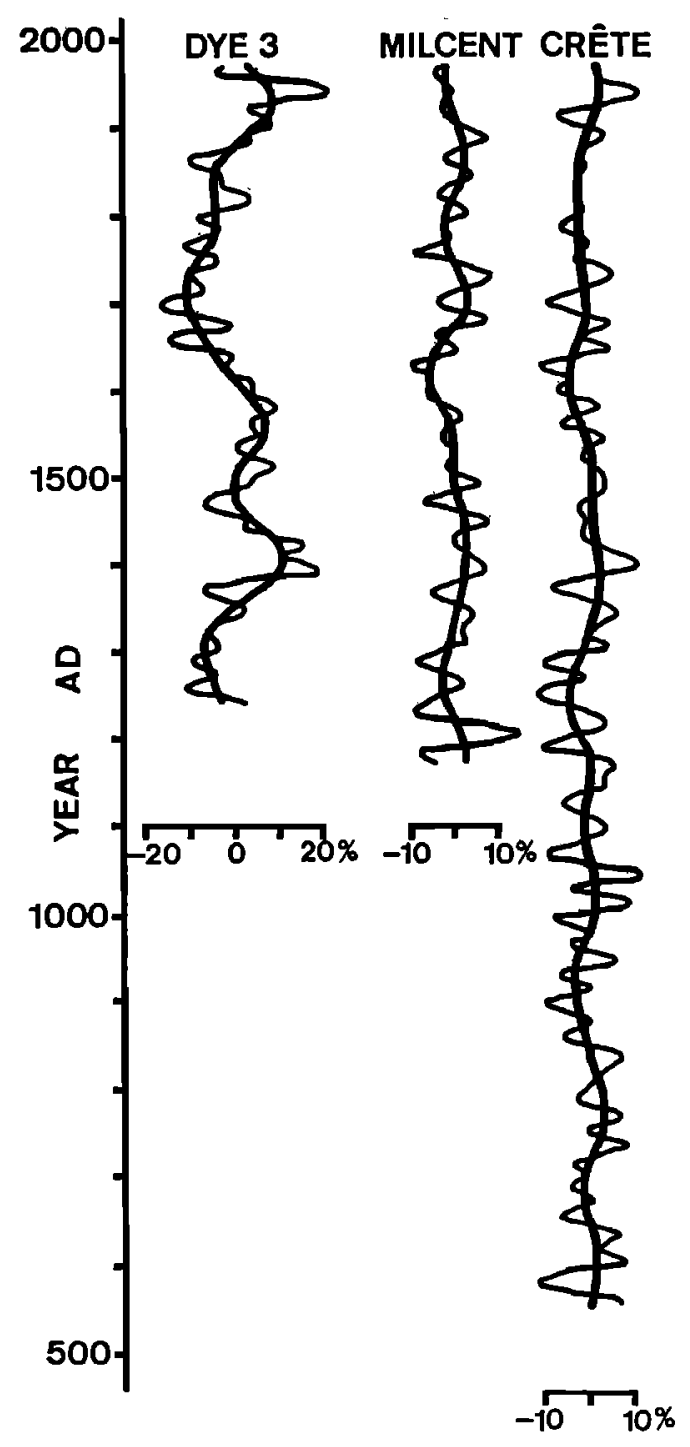

Figure 8. Accumulation rate records from three Greenland stations, derived from deep ice cores. Annual data series have been smoothed by digital low-pass filters with cutoff periods of 120 years (heavy curves) and 30 years (thin curves). (From Reeh et al. [1978]; reproduced by courtesy of the Intemational Glaciological Society and the authors.) 
To obtain more accurate values of surface lowering for an area of 1-m radius around the stake, Müller and Keeler [1969] designed a star ablatometer. This is a six-arm metal star that is mounted on the survey stake. Each arm has six sleeved holes, thus 36 points can be measured by lowering a measuring rod through each hole. This way, some information on the local variability in weathering of the crust is obtained. This method therefore provides a more accurate assessment of ablation than the straight-edge method. However, changes in the weathering crust from one reading to the next may be a source of uncertainty.

Instead of estimating ablation from surface lowering only, which may be more representative of variations in surface density rather than true ablation, the latter can be determined by measuring changes in mass. LaChapelle [1959] discusses a practical method for this. Referring to Figure 9, at some initial time $t_{0}$ the thickness of a surface layer equals $h_{o}$ and has a known vertical distribution of bulk density, $\rho\left(h, t_{o}\right)$. After a time interval $t_{1}-t_{o}$ has elapsed the surface has lowered and the thickness has decreased by an amount $\delta h$. Because the density close to the surface is, in general, not constant with time, the loss of mass in the surface layer is given by

$$
\Delta M=\int_{0}^{h_{0}} \rho\left(h, t_{0}\right) d h-\int_{0}^{h_{1}} \rho\left(h, t_{1}\right) d h,
$$

which equals the shaded area between the two density curves in Figure 9. Obviously, this method is rather tedious as it requires sufficient measurements of density to determine the density-depth curve.

Finally, ablation can be estimated from measurements of surface runoff, provided the firn is impermeable, and evaporation is negligible. Because of the time lag between the melt and the surface discharge, this method is not very reliable to determine daily melt rates.

From comparison of the different techniques discussed above, Müller and Keeler [1969] conclude that the direct measurement of mass loss (surface lowering plus melt in the upper crust) appears to give the best estimates of true ablation.

\subsection{Mass Balance of a Drainage Basin}

To assess the mass balance of a drainage basin of a glacier, the net input has to be compared to the net output. As an example, consider the study of Whillans and Bindschadler [1988] for ice stream B, West Antarctica.

Because ice flow is almost perpendicular to surface elevation contours, the boundaries of the drainage basin can be determined by drawing flow lines perpendicular to elevation contours. This requires an accurate map of surface topography, which for ice stream $B$ has been constructed by Shabtaie et al. [1987], based on airborne radar. Some ambiguity in the boundaries of the catchment area is unavoidable (see Figure 10). This could be lessened if surface velocities are available, indicating the direction

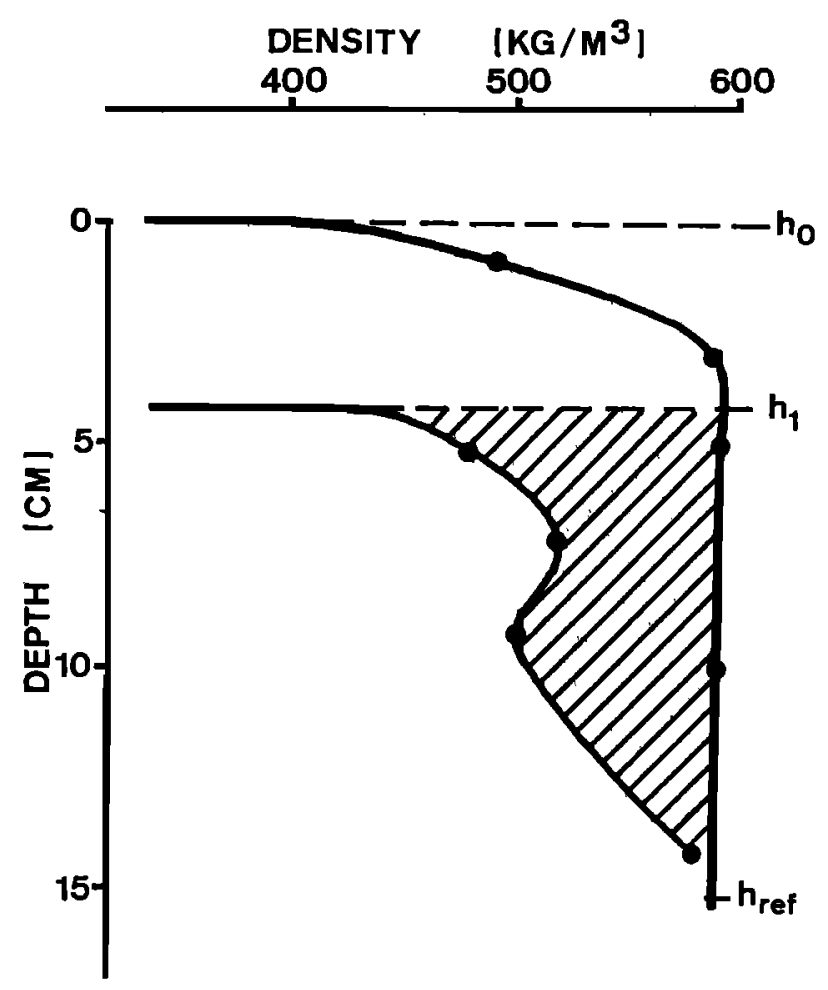

Figure 9. Measurement of direct mass loss on Blue Glacier, 1958. (From LaChapelle [1959]; reproduced by courtesy of the International Glaciological Society and the authors.)

of flow. For ice stream $B$ the maximum and minimum size of the catchment area differ by $12 \%$ from the average value, $147,000 \mathrm{~km}^{2}$ [Whillans and Bindschadler, 1988].

Accumulation rates were determined from the gross beta activity profiles of shallow cores, as discussed in section 5.1. Also available for this region are earlier values from Bull [1971]. The variability apparent in the accumulation rates shown in Figure 10 is mainly due to local surface slope effects; sastrugi and interannual variability contribute to a lesser extent to the variability. The areally weighted mean accumulation rate is $0.143 \pm 0.014 \mathrm{~m} \mathrm{yr}^{-1}$.

Basal melting results in loss of ice that is not accounted for by the discharge measured downstream. However, this appears to be negligible and is estimated at $0 \pm 0.005 \mathrm{~m}$ $\mathrm{yr}^{-1}$ by Whillans and Bindschadler [1988].

The outflow is calculated through a gate across the narrowest part of the ice stream. About 787 surface velocities on the transect are derived from repeat aerial photogrammetry, with ground control provided by Transit satellite tracking stations (cf. Whillans and Bindschadler [1988] for a discussion of the procedure involved). In short, positions of surface features (crevasses, drift mounds, etc.) that appear on both sets of photographs are measured, and velocities are calculated from the difference in position and the elapsed time interval. Whillans and Bindschadler [1988] estimate the error limits for these velocities to be $\pm 12 \mathrm{~m} \mathrm{yr}^{-1}$. The surface velocity profile along the transect is shown in Figure 11. Because almost 


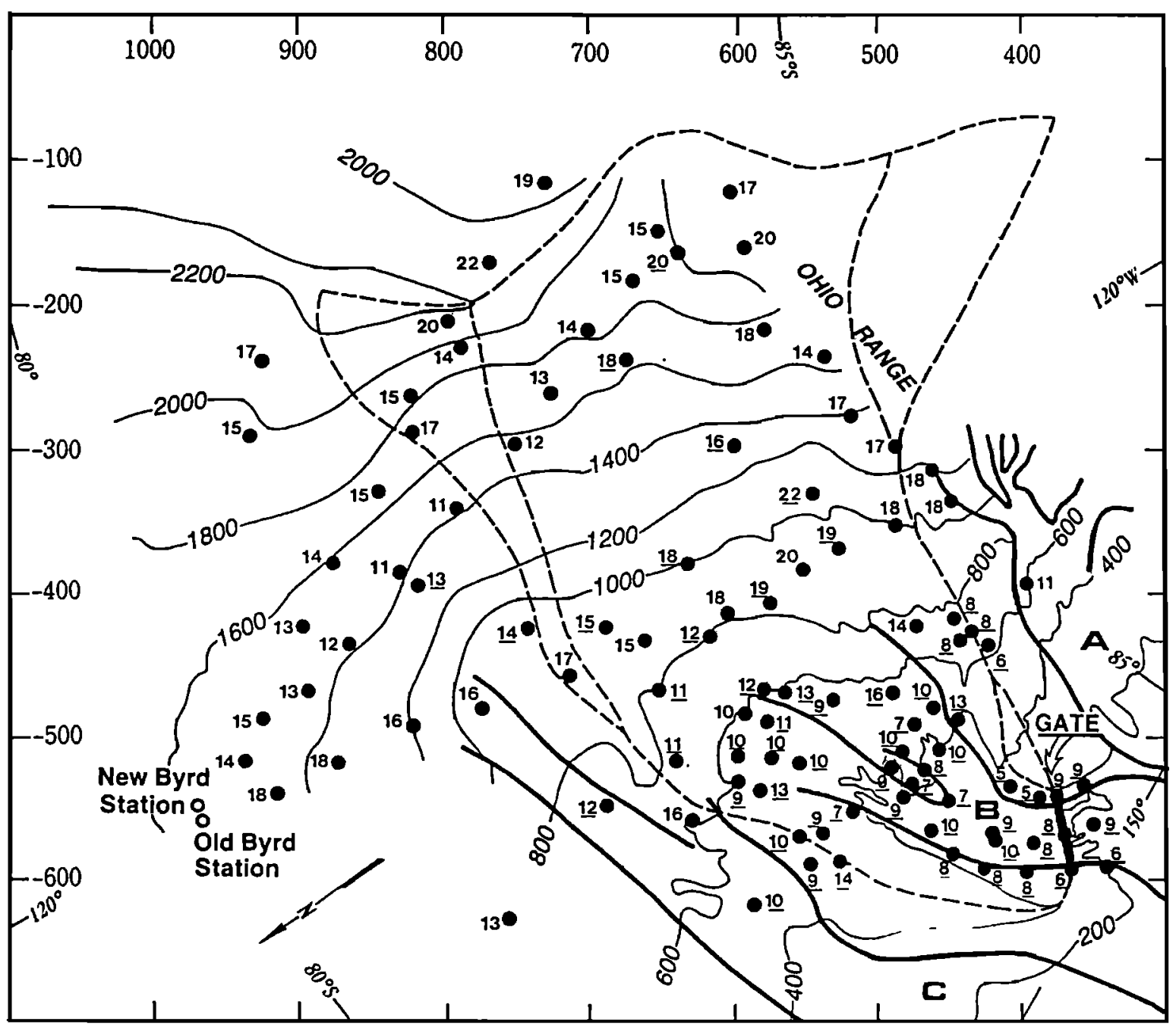

Figure 10. Map of the ice stream B drainage basin, with accumulation rates in centimeters per year. Underlined values are derived from measurements of gross beta activity, while other values are from Bull [1971]. Dashed lines indicate possible boundaries of the catchment area. (From Whillans and Bindschadler [1988]; reproduced by courtesy of the International Glaciological Society and the authors.)

all ice motion is due to basal sliding on ice stream B, these velocities are representative of the depth-averaged velocities.

Ice thickness across the ice stream is also shown in Figure 11. These were determined from a radio echo sounding flight and are believed to be accurate to $\pm 18 \mathrm{~m}$ [Shabtaie and Bentley, 1987].

With these data the net mass balance of the drainage basin can now be addressed. Multiplying the mean surface accumulation for each 200 -m elevation interval by the area of that interval gives the net input of ice $\left(21.4 \pm 5.2 \mathrm{~km}^{3}\right.$ $\mathrm{yr}^{-1}$ ). The error, which also includes the uncertainty due to basal melting, originates from uncertainties in the accumulation rate and in the areal extent of the basin. By integrating the velocity profile on the transect over the ice thickness the discharge through the gate is found to be $\mathbf{3 0 . 0}$ $\pm 1.0 \mathrm{~km}^{3} \mathrm{yr}^{-1}$. The difference between the input and output is $-8.6 \pm 6.2 \mathrm{~km}^{3} \mathrm{yr}^{-1}$, which corresponds to an average thinning rate of $0.06 \pm 0.04 \mathrm{~m} \mathrm{yr}^{-1}$. The most important uncertainties in this estimate are associated with the sparse accumulation rate data above the $1000-\mathrm{m}$ elevation contour and with the accuracy of determining the boundaries of the catchment area.

\subsection{Mass Balance of Mountain Glaciers}

The most frequently used method for determining changes in the mass balance of a glacier is mapping historic front variations. Most of the information pertaining to glacier behavior during the Little Ice Age is based on such records. However, changes in length are not necessarily proportional to changes in ice volume. For example, Nigardsbreen in Norway has a wide accumulation area and a long narrow tongue, and is very sensitive to small perturbations. A better measure of volume changes is 
obtained by taking into account geometric effects. Oerlemans [1988] proposes to scale the length variations by a characteristic length, defined as the ratio of glacier area to mean width of the tongue. This improves the correlation between front variations and ice volume on longer time scales, but as pointed out by Meier [1984], measurements of advance or retreat can be misleading in sign. It is possible for a glacier to increase in volume, while its front is retreating at the same time.

A more quantitative estimate of the mass balance of a glacier can be obtained by considering the terms in the mass balance equation,

$$
\begin{aligned}
\delta M & =N-A-V \\
& =R-B,
\end{aligned}
$$

where $\delta M$ represents the change in ice volume, $N$ the total precipitation, $A$ the discharge, $V$ total evaporation, $R$ the net accumulation, and $B$ the net ablation.

In the hydrological method the water balance of a precipitation basin that includes the glacier is considered. This means that meteorological data for the area surrounding the glacier are required to estimate the total precipitation $N$. The discharge $A$ can be measured by stream gauges, downstream of the glacier front. A difficulty with this method is that the change in ice volume, $\delta M$, is usually the small difference between the two large numbers, $N$ and $A$, and the smaller, and much lesser known, evaporation $V$. Hoinkes [1970] points out that the hydrological method

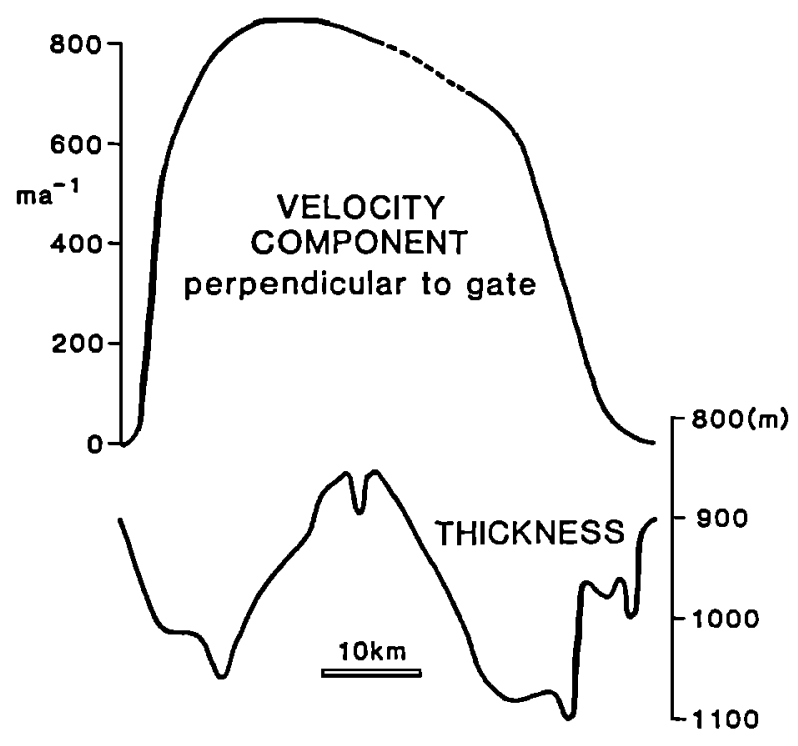

Figure 11. (Top) Velocity from repeat photogrammetry; the dashed part is interpolated because of lack of traceable surface features. (Bottom) Thickness profile derived from radio echo sounding. (From Whillans and Bindschadler [1988]; reproduced by courtesy of the International Glaciological Society and the authors). may be expected to yield results that vary too much from year to year. During dry summers the glacier's mass balance tends to be underestimated, while after a wet summer the calculated mass balance may be too large.

The glaciological method restricts measurements to net accumulation on the glacier $R$ and net ablation $B$. Both can be determined by the techniques discussed above. For example, Hoinkes and Rudolph [1962] and Hoinkes [1970] apply the glaciological method to study the mass balance of the Hintereisferner in the Austrian Alps. Accumulation rates were determined from pit studies, while ablation was measured using ablation stakes. The volume of this glacier has been steadily decreasing, at least until about the mid-1960s.

A completely different technique for measuring changes in ice volume is the geodetic method. Accurate topographic maps compiled at different times have to be available for this [e.g., Finsterwalder, 1962]. To obtain reliable estimates of change, the contour lines must be determined with an accuracy of at least a few decimeters. Such precision can be achieved either by classical surveying methods or by stereo-photogrammetry with controls provided by reference elevations on the neighboring solid rock. The major advantage of this method is that glacier changes over a few years can be measured with relatively little field effort. Inaccuracies in measuring the surface elevation on especially the snow-covered parts of the glacier can lead to uncertainties that are too large for application to year-to-year changes.

\subsection{Numerical Methods}

By combining field measurements with a theoretical or numerical model the mass balance can be estimated. The most straightforward method is to calculate balance velocities required for steady state conditions and compare these with measured surface velocities. This can be done for an entire ice sheet [e.g., Budd and Smith, 1985], for a drainage basin [e.g., Bindschadler, 1984], or along a transect [e.g., Kostecka and Whillans, 1988]. The balance velocity is calculated from surface elevations and ice thicknesses and from accumulation data. A difficulty with this method is that the calculated balance velocities correspond to the depth-averaged ice flux. Thus, to allow for comparison with observed surface velocities, an assumption about the vertical variation in the horizontal ice velocity has to be made. If basal sliding is relatively large, this variation is negligible and calculated balance velocities can be directly compared with surface velocities. However, for an ice sheet frozen to the bed the velocity at the ice surface may be significantly larger than the depth-averaged velocity. Combined with uncertainties associated with the constitutive relation for polar ice [cf. Van der Veen and Whillans, 1990], this technique necessarily introduces large error limits.

On a smaller scale the mass balance can be estimated from flux divergence considerations [Mellor, 1968; Reeh and Gundestrup, 1985]. Integrating the equation of 
continuity over the ice depth yields an expression relating the rate of thickness change to surface accumulation, ice velocity, and principal strain rates in the flow direction and cross-slope direction. Because measurements only provide surface values of velocity and strain rates, some assumptions about their variation with depth have to be made. For this, Reeh and Gundestrup [1985] introduce a shape factor of the horizontal velocity profile, which is assumed not to vary horizontally. The depth variation in horizontal velocity and the shape factor can be derived from measurements of borehole tilting. The main advantage of this method is that many sites can be investigated with relatively simple field programs. A problem associated with the technique is that calculated thickening rates may be heavily influenced by local flow effects. This can be alleviated by using regional values or by investigating many neighboring sites and validating the results on a statistical basis.

Whillans [1977] applies the depth-integrated continuity equation to the flow along the Byrd Station Strain Network, upstream of Byrd Station, West Antarctica. By integrating this equation along the flow line starting at the ice divide, a comparison between the true ice velocity and the balance flux can be made. Separating the contributions to the total velocity from basal sliding and from internal shear is an important source of uncertainty.

Many other techniques exist, such as modeling the ice flow along a flow line, or part thereof, and explicitly calculating the time evolution [e.g., Huybrechts and Oerlemans, 1989]. The level of confidence that can be placed on such studies is largely determined by the simplifying assumptions involved, and by the sensitivity of the results to poorly known parameters, most notably the rate factor in the constitutive relation.

\section{SATELLITE APPLICATIONS IN GLACIER MASS BALANCE STUDIES}

\subsection{Altimetry Over Ice Sheets}

Satellite radar altimetry was used by Zwally et al. [1983] to map the surface topography of parts of the Greenland ice sheet (south of $72^{\circ} \mathrm{N}$ ) and the Antarctic ice sheet (north of $72^{\circ} \mathrm{S}$ ). They used more than 600,000 elevation measurements over both ice sheets from the radar altimeter on-board Seasat (in operation from June to October 1978). Because this altimeter was designed for use over oceans, which are virtually horizontal with smallscale roughness, applications to ice sheets require special treatment of the data (in addition to the corrections for atmospheric effects and adjustments for radial orbit errors). First, because of small-scale undulations, the altimeter experienced considerable difficulty in predicting successive ranges to the ice surface. Where the surface disturbances are too large, no return waveform was recorded, whereas over the remaining areas the slow response of the tracker caused an error in each range measurement of typically several meters. By applying a retracking procedure that fits a multiparameter function to each waveform, Martin et al. [1983] were able to eliminate most of this error. A second source of uncertainties is associated with the large-scale slope of the ice surface. The measured ranges are from the satellite to the part of the surface that is closest to the satellite. On a sloping surface this point is not the same as the subsatellite point (nadir). Rather, the reflecting point is displaced upslope from the point directly beneath the satellite which introduces a slope-induced error between the true range to the nadir and the measured range. For the Seasat altimeter this error is almost $80 \mathrm{~m}$ for an $0.8^{\circ}$ slope [Brenner et al., 1983]. In the coastal areas of ice sheets, large slopes often occur, and the altimeterderived elevations are least accurate. The slope-induced error could be minimized by reducing the beam width of the altimeter (3- $\mathrm{dB}$ half angle beam width of $0.8^{\circ}$ for the Seasat altimeter) [Bindschadler et al., 1989b]. By narrowing the beam, most of the beam energy is focused close to the subsatellite point, thereby avoiding the possibility of returns from points that are closer to the satellite, but away from the nadir. Narrower beams require a different altimeter design, for example, synthetic radar or laser altimeters.

Bindschadler et al. [1989b] give a comparison between satellite altimeter elevations of the Greenland ice sheet and other elevation measurements. These include elevations derived from Transit (Doppler) satellite receivers and from the optical leveling along the EGIG line. Figure 12 shows the altimeter-derived elevation contours, as well as the sites for comparison. For all comparisons the Seasat elevations are lower than those measured otherwise, as shown in Figure 13. Along the EGIG traverse a systematic trend exists, with the largest absolute differences occurring closer to the ice sheet margin. This may be caused by a combination of larger slope-induced errors and a rougher ice surface near the exterior. It is not clear, however, why the Seasat elevations are consistently lower. It could be that these differences are due to different gravity models used to generate the orbit ephemerides for the Seasat and the Transit satellites. However, this does not explain the differences between the Seasat elevations and those along the EGIG line, derived from optical surveying. Another possibility is that the radar pulse penetrates into the ice sheet surface, which alters the shape of the return waveform. Ridley and Partington [1988] suggest that this error can result in an underestimate of the elevation by as much as $3.3 \mathrm{~m}$, depending on the retracking method used in the data reduction. Penetration is most likely to occur in the regions of highest elevation, which is where Bindschadler et al. [1989b] found the largest differences. Finally, the possibility that the differences represent real elevation changes cannot be ruled out. However, there are insufficient data to eliminate or confirm this possibility.

On a smaller scale, Seasat observations over a $100-\mathrm{km}^{2}$ area in southern Greenland are compared to a detailed, ground-based survey by Gundestrup et al. [1986]. Their 


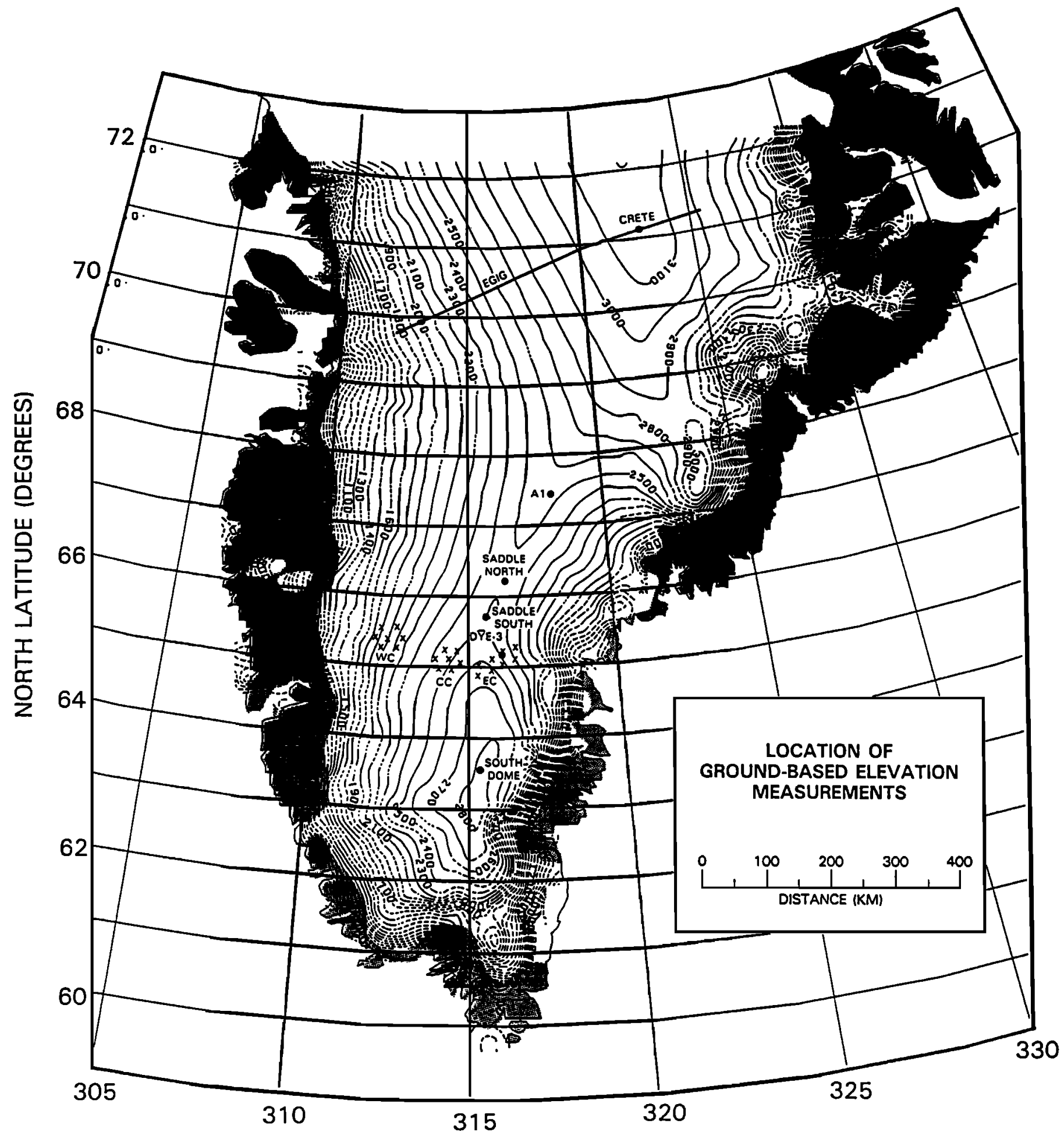

EAST LONGITUDE (DEGREES)

Figure 12. Elevation contours for the Greenland ice sheet (south of $72^{\circ} \mathrm{N}$ ) determined from satellite antimetry and location of the sites of ground observations used for comparison [from Bindschadler et al., 1989b]. 


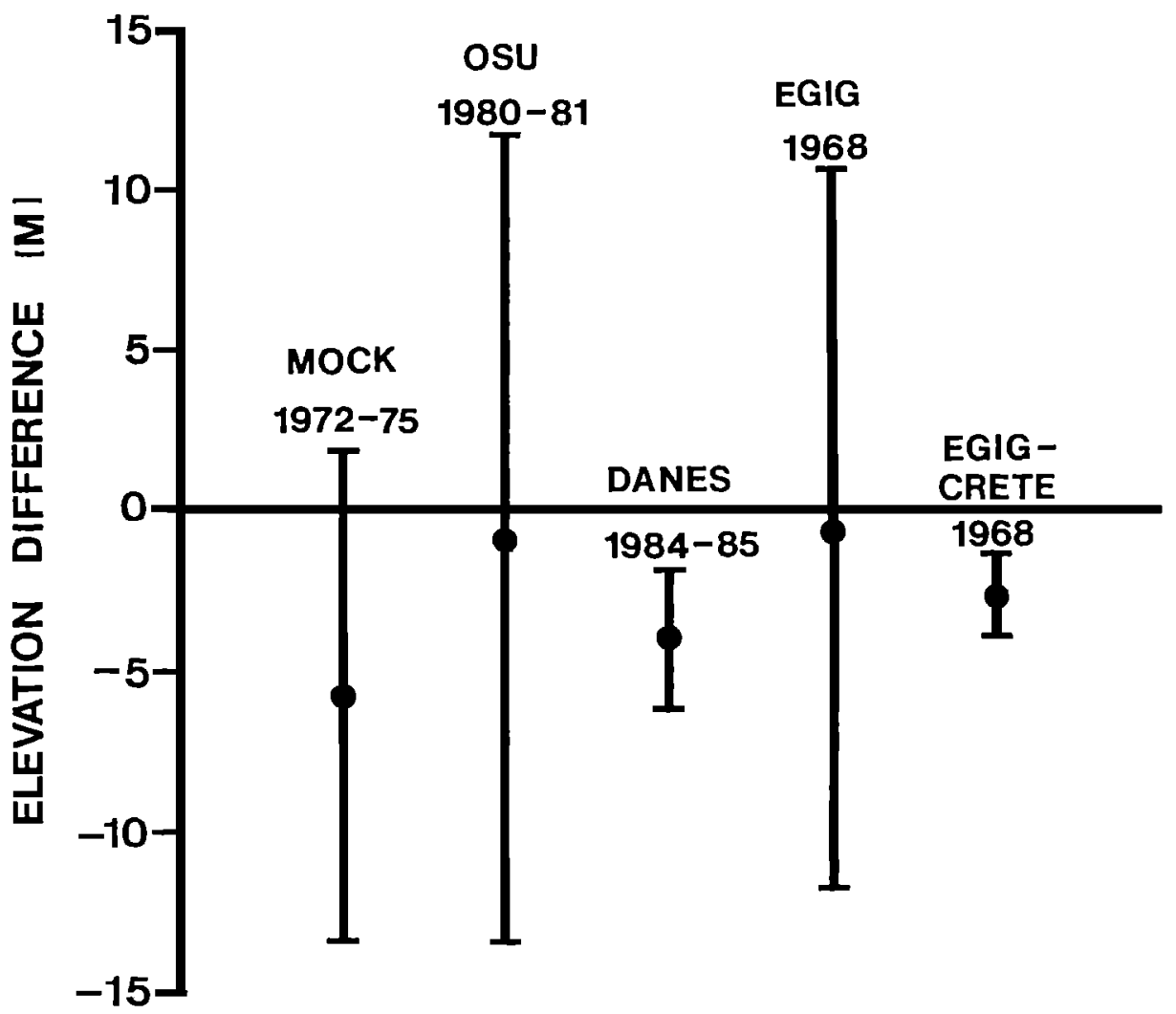

Figure 13. Mean elevation differences for the comparison between altimeter-derived elevations and those from conventional techniques. The years indicate when the ground-based measurements were performed. The length of the vertical bars corresponds to one standard deviation [from Bindschadler et al., 1989b].

conclusion is that the altimeter range measurements are accurate to the level of the geoceiver-determined surface (2 m). However, the altimeter tends to lock onto hills and peaks in the surface topography near the subsatellite track; the lower parts between the hills cannot be resolved, because the altimeter jumps from one topographic high to the next. Thus the range measurements overestimate the true surface elevation. Because a similar altimeter may be expected to make comparable errors when remeasuring the surface elevation, changes in ice thickness may be detectable with higher accuracy.

\subsection{Changes in Ice Thickness}

Repeat measurements of surface elevation offer a method to determine changes in ice volume, as demonstrated by Zwally et al. [1989]. These authors used data collected over the Greenland ice sheet (south of $72^{\circ} \mathrm{N}$ ) by radar altimeters on board the GEOS 3 (in operation from April 1975 to June 1978), Seasat (July to September 1978), and Geosat (launched in March 1985; data from the first 18 months were used). Changes in surface elevation were determined where successive subsatellite paths intersect.

Zwally et al. [1989] applied two methods to calculate elevation changes. Where a large number of measurements are available for two distinct periods by a relatively large time interval ( $d t=7$ years, for the Geosat-Seasat comparison), changes in elevation can be computed from the average crossover height difference divided by the time interval. That is,

$$
\frac{d H}{d t}=\frac{1}{d t} \sum_{i}\left(H_{2}-H_{1}\right)_{i} / N
$$

where $\left(H_{2}-H_{1}\right)_{i}$ is the elevation difference at the $i$ th crossover and $N$ the number of crossovers. If the repeat measurements have randomly distributed time intervals, the $d H / d t$ method is more appropriate. Assuming that elevation changes are a linear function of time, and assuming that the data are randomly distributed around this trend, the slope of a linear fit to the crossover differences versus their time intervals gives the rate of elevation change. The advantage of this technique is that all repeat measurements can be used (instead of only those made over the specified time interval $d t$ ) and that the effect of possible seasonal changes in either the surface elevation, or radar backscattering properties, is reduced (because there may be summer-winter and winter-summer measurements). Also, any measurement bias can be detected by considering the intercept of the linear fit at zero time difference.

The elevation differences obtained from either method contain a random error. Zwally et al. [1989] determine the magnitude of this error from repeat altimeter measurements over short time intervals (less than 15 days). Depending on the data set, the standard error for single measurements can be a few meters. However, even though this means that the error in elevation difference is usually larger than the actual change in elevation, significant values can be obtained if a sufficiently large number of repeat observations is available. Lingle et al. [1990] use semivariogram methods to estimate the noise in the altimeter measurements as a function of position (the semivariogram is analogous to the autocorrelation function used in analysis of time series). Mean elevation changes 
are computed by averaging the elevation differences obtained at points where orbits ascending in latitude are later crossed by orbits descending in latitude (or vice versa). Each crossover difference is weighted in proportion to the inverse square of the noise level in the vicinity of the crossover point. The advantage of this method is that the influence of areas with exceptionally high noise levels is minimized. Also, the noise estimate does not depend on a priori knowledge of error sources such as instrument calibration or radial orbit errors. This means that this method may be suitable for detecting changes in mean surface elevation near the margins of ice sheets, where altimeter noise levels are high and variable, due to steep surface slopes and rough surface topography.

For mass balance studies, changes in ice thickness are of more interest than those in surface elevation. This means that the derived elevation changes have to be corrected for vertical motion due to postglacial isostatic adjustment and the densification of firn. Zwally [1989] argues that for southern Greenland both effects are likely to be small so that the inferred change in volume can be directly equated to the measured elevation change times the ice sheet area.

\subsection{Surface Melting}

The intensity of microwave radiation thermally emitted by an object is usually expressed in terms of the brightness temperature $T_{b}$, the emissivity of the object times its actual temperature. The application of microwave radiometry as a remote sensing tool is based on the fact that the emissivity of an object depends mainly on its composition and physical structure. Thus measurements of the brightness temperature provide information on the emissivity when the physical temperature can be independently estimated. If the emissivities of the radiating surface are known, measurements of $T_{b}$ can be used to infer the physical properties of the radiating media. The brightness temperature of snow increases markedly with wetness [Stiles and Ulaby, 1980], and the rise in $T_{b}$ at the onset of surface melting is easily detected. For instance, in the percolation zone in Greenland the increase in brightness temperature during the period of summer melting is about $80 \mathrm{~K}$ compared to the winter value [Zwally, 1984, Figure 6].

Zwally [1977] developed a theory for calculating the emitted radiation of an ice sheet as a function of measured temperature and profiles of grain size. Measured emissivities are determined by taking the ratio of observed brightness temperature to the mean annual temperature derived for the surface station. Comparison between emissivities thus determined and emissivities calculated from the theory were very satisfactory. Because the snow crystal size depends on the snow accumulation rate and the mean annual surface temperature, the effect of changes in either one of these quantities on the bulk emissivity and brightness temperature can be estimated. Zwally [1977] calculates that a $1^{\circ}$ change in snow temperature has the equivalent effect of a $10 \%$ change in accumulation rate; the emissivity changes by about 0.003 to 0.014 , corresponding to a change in brightness temperature of about 0.6 to $3 \mathrm{~K}$. Comiso et al. [1982] expanded the radiative transfer model used in these calculations and produced comparisons between seasonal variations in brightness temperature and predicted variations calculated from the measured snow temperature and grain size profiles.

These studies used observations made over the polar ice sheets by the electrically scanning microwave radiometer (ESMR) on board the Nimbus 5 spacecraft, launched in 1973. This radiometer operated at a single frequency (18 $\mathrm{GHz}$ ) and a single polarization. This means that the different geophysical properties that contribute to changes in brightness temperature are not readily separated without additional information (such as the physical temperature of the snow pack). With the dual-frequency data obtained from the scanning multichannel microwave radiometer (SMMR) a distinction between changes in the physical temperature of the snow and changes in the electrical properties of the snow becomes potentially feasible. In an exploratory study, Jezek et al. [1990] found that differences in the amplitude and swing of both channels (18 and $37 \mathrm{GHz}$ ) are generally explainable in terms of electromagnetic principles. The amplitude swing of the $27-\mathrm{GHz}$ channel is larger than that of the $18-\mathrm{GHz}$ channel, reflecting the increased thermal mass associated with the deeper-penetrating 18-GHz waves. Differences in bulk emissivities due to the different penetration depths result in shifts in mean values of brightness temperatures measured by like polarization channels (that is, brightness temperatures for both horizontally polarized channels or both vertically polarized channels). Differences between brightness temperatures of horizontally and vertically polarized channels are associated with differences in Fresnel reflection coefficients for each polarization.

Such differences between the frequency and polarization response of each channel suggest that valuable information on the surface climate of ice sheets (for example, the onset and extent of surface melting) may be derivable from comparison of the two channels. K. C. Jezek (personal communication, 1990) believes that variations in the polarization rate, which is defined as

$$
P=\frac{T_{b V}-T_{b H}}{T_{b V}+T_{b H}}
$$

where $T_{b V}$ and $T_{b H}$ are the brightness temperatures for the vertical and horizontal channels of particular frequencies can be used to detect melt features. If this idea can be substantiated, it will represent a significant improvement of our ability to observe melt patterns on the polar ice sheets. Not only will it be possible to monitor surface melt over large areas of the ice sheets (which is not very feasible with conventional field programs), but this method will also allow for early detection of changes in these patterns, which may be indicative of changes in the polar climates. 


\subsection{Other Applications}

In addition to the areas discussed above, satellite imagery and remote sensing offer many other opportunities for studying and monitoring the cryosphere. Perhaps the most developed application is the mapping of sea-ice extent and variations in it [Swift and Cavalieri, 1985; Parkinson et al., 1987; Zwally and Walsh, 1987]. Also, imagery has been applied to infer changes in the seaward boundaries of Antarctic ice shelves [Swithinbank, 1970; Partington et al., 1987; Zwally et al., 1987]. Although both these applications do not pertain directly to the study of mass balance of terrestrial ice, they are important in that changes in the grounded ice masses are likely to be preceded by changes in the extent of sea ice and migration of ice shelf margins.

Vast areas of the Antarctic ice sheet are still poorly mapped. Satellite imagery provides the only practical means for viewing the entire ice sheet, because, in many cases, the horizontal scale of topographic features is too large for standard ground-based surveying techniques. Bindschadler and Vornberger [1990] use advanced very high resolution radiometer (AVHRR) imagery to describe and interpret surface features in the Siple Coast Region of West Antarctica. Although these images have a lower resolution than, for example Landsat, there are major advantages to using AVHRR. The swath of the imaging system is typically much wider than that of the highresolution system so that data collection can be extended to the geographic pole (Landsat coverage ends at $82.6^{\circ} \mathrm{S}$, while SPOT does not reach beyond about $86^{\circ} \mathrm{S}$ ). Furthermore, the coverage is more frequent so that chances of collecting cloud-free data are greatly improved. Also, the wide swath eliminates the need for compositing many scenes together. The image discussed by Bindschadler and Vornberger [1990] shows many surface features that can be interpreted in terms of glacier dynamics. For mass balance studies, monitoring the position of the grounding line is of primary interest. Bindschadler and Vornberger [1990] argue that the grounding line should be identifiable by the transition from an undulated ice stream to the smooth ice shelf, as can be seen as the mouth of ice stream D. The pixel size $(1.1 \mathrm{~km}$ after being geometrically corrected and resampled) determines the accuracy of the grounding line position. However, because of the shallowness and relatively flat profile of the subglacial bed, small changes in thickness of the ice streams may result in large movements of the grounding line, which should be readily detectable on these images.

For glacier dynamics studies, surface velocities and strain rates are very important. The ice motion determines the rate of discharge from the interior parts of ice sheets to the ocean. Strain rates provide insight into processes associated with deformation and sliding of the ice masses and help in understanding the funneling of ice flow into outlet glaciers and ice streams. From repeat imagery, velocities and their gradients (strain rates) can be determined in a similar fashion as repeat aerial photography
[Mellor, 1958; Morgan, 1973; Krimmel and Meier, 1975; Brecher, 1986; Whillans and Bindschadler, 1988]. For example, Lucchita and Ferguson [1986] use successive Landsat images of Byrd Glacier draining the East Antarctic ice sheet through the Transantarctic Mountains into the Ross Ice Shelf. Many surface features on this glacier remain preserved and visible over periods of many years so that tracking these features allows measurement of glacier velocity. The average displacement over an interval of nearly 10 years (January 1974 to November 1983) is 7.5 to $8 \mathrm{~km}$, giving a velocity of 750 to $800 \mathrm{~m} \mathrm{yr}^{-1}$. This velocity is comparable to those established by ground-based and aerial survey of this glacier. Thus repeat satellite imagery provides a rapid and cost-effective method of obtaining average surface velocities. Whether or not the accuracy of these velocities is sufficient for detailed studies of ice sheet dynamics remains to be proven.

\section{CONCLUDING REMARKS}

Despite more than 30 years of multinational efforts the mass balance of the two polar ice sheets, as well as that of smaller ice caps and mountain glaciers, is poorly known. For areas of the polar ice sheets that have been studied extensively, error estimates are high with the limits encompassing both thickening and thinning. Improving our knowledge and refining current estimates is imperative before any credible assessment of the effects of a global warming on the cryosphere, and the associated consequences for sea level, can be made. This means that a coherent program aimed at accurately determining the mass balance of those components of the cryosphere that could adversely affect global sea level is needed.

Conventional ground-based surveys are time consuming and costly so that the area of coverage has to be limited. The main advantage of such programs is that the techniques involved are well tried, and errors can be assessed directly and, if necessary, reduced by additional fieldwork. The application of satellite measurement techniques is relatively new in glaciology. Pioneering studies have shown that satellite imagery has many potential applications, such as direct measurements of thickness changes, or movement of the ice sheet edges. However, there are still large uncertainties prohibiting high accuracy. Therefore a combination of different techniques covering the full range of data is required to validate the observations from satellites. Ground-based surveys of velocities and accumulation rates in key areas, repeated over long time periods (years to decades), are still needed to control the interpretation of satellite data. Of course, the great advantage of satellite remote sensing techniques is the potential large areal coverage and the almost continuous time coverage it could have.

Because the West Antarctic ice sheet is generally acknowledged as posing a major threat, a large number of glaciological studies have concentrated on this region. The 
threat arises from the fringing ice shelves hypothesis, suggesting that a decrease in the buttressing role of the peripheral ice shelves may lead to the collapse of the ice sheet [e.g., Mercer, 1978]. This possible dire effect of the anticipated greenhouse warming warrants all efforts put into better understanding the intricacies of ice flow and detecting ongoing changes in the environment of West Antarctica. However, this focusing of attention on this particular ice sheet does not imply that other components of the cryosphere are not equally important. Because of its vastness, relatively small changes in East Antarctica can have large effects. For example, the direct effect of a $10 \%$ increase in precipitation (as found by Manabe and Stouffer [1980] for a doubling of the atmospheric $\mathrm{CO}_{2}$ content) is a lowering of sea level at a rate of about $27 \mathrm{~cm}$ per century. Of course, this number may be modified through the dynamic response of the ice sheet, but it clearly illustrates the importance of accurate measurements.

Monitoring the margins of ice masses may help in early detection of changes. Ablation rates, calving rates, and basal melting of ice shelves along with ocean temperatures need to be assessed more accurately as the effect of the anticipated greenhouse warming is likely to manifest itself in these areas first. However, the differential response of different regions, particularly interior versus coastal, highlights the need for complete coverage.

The importance of long-term records for detecting climate change has been well established. Unfortunately, very few such records exist. The longest records, spanning the past 160,000 years, were obtained from the Vostok ice core. Jouzel et al. [1987] interpret the continuous deuterium profile along the 2083-m-long core, in terms of atmospheric temperature changes, while Barnola et al. [1987] provide a record of atmospheric $\mathrm{CO}_{2}$ inferred from gas trapped in the ice. Other often used climate records include the $\mathrm{CO}_{2}$ measurements at Mauna Loa, Hawaii, and the south pole (started around 1958), temperature records (the longest ones reaching back to the early 1800s) and tide gauge records. Because of the natural variability of climate, observations over extended periods of time are required before any trend can be unambiguously detected. The same holds for variations in the volume of terrestrial ice. Monitoring global ice volume and establishing quantitative records of changes in it are long overdue and should be a priority among glaciologists and the "global change" community in general.

ACKNOWLEDGMENTS. I thank Bob Bindschadler, Ken Jezek, Bob Thomas, and Ian Whillans for helpful suggestions and comments on earlier versions of this paper. Thanks are due to Lymn Lay for hunting down most references and to Kathleen Doddroe for typing the manuscript. This work was supported by U.S. National Science Foundation grant DPP-8716447-A02 and the National Aeronautics and Space Administration grant NAGW-2129. Byrd Polar Research Center contribution 734.

Ann Henderson-Sellers was the Editor responsible for this paper. She thanks Bill Budd and Kendal McGuffie for their careful technical reviews and Ray Arvidson for his assistance as the cross-disciplinary referee.

\section{REFERENCES}

Allison, I., The mass budget of the Lambert Glacier drainage basin, Antarctica, J. Glaciol., 22, 223-235, 1979.

Bader, H., The Greenland ice sheet, report, part I, section B2, 18 pp., U.S. Army Cold Regions Res. and Eng. Lab., Cold Reg. Sci. and Eng., Hanover, N. H., 1961.

Barnola, J. M., D. Raynaud, Y. S. Korotkevich, and C. Lorius, Vostok ice core provides 160,000 -year record of atmospheric $\mathrm{CO}_{2}$, Nature, 329, 408-414, 1987.

Bauer, A., The balance of the Greenland ice sheet, J. Glaciol., 2, 456-462, 1955.

Bauer, A., Le bilan de masse de l'indlandsis du Groenland n'est pas positif, IAHS Publ., 11(4), 8-12, 1966.

Bauer, A., A. Ambach, and O. Schimpp, Mouvement et variation d'altitude de la zone d'ablation ouest de l'indlandsis du Groenland entre 1948 et 1959, Medd. Groenl., 174(1), 79 pp., 1968.

Benson, C. S., Stratigraphic studies in the snow and firn of the Greenland Ice Sheet, Res. Rep. 70, 93 pp., Snow, Ice, and Permafrost Res. Estab., Hanover, N. H., 1962.

Bentley, C. R., Glaciological evidence: The Ross Sea sector, Glaciers, Ice Sheets, and Sea Level: Effect of a $\mathrm{CO}_{2}$-Induced Climatic Change, Rep. DOE/EV/60235-1, pp. 178-196, U.S. Dep. of Energy, Washington, D. C., 1985.

Bindschadler, R. A., Jakobshavns Glacier drainage basin: A balance assessment, J. Geophys. Res., 89, 2066-2072, 1984.

Bindschadler, R. A., and P. L. Vomberger, AVHRR imagery reveals Antarctic ice dynamics, Eos Trans. AGU, 7I, 741-742, 1990.

Bindschadler, R. A., E. P. Roberts, and D. R. MacAyeal, Distribution of net mass balance in the vicinity of Crary Ice Rise, Antarctica, J. Glaciol., 35, 370-377, $1989 a$.

Bindschadler, R. A., H. J. Zwally, J. A. Major, and A. C. Brenner, Surface topography of the Greenland ice sheet from satellite radar altimetry, NASA Spec. Publ. SP-503, 105 pp., $1989 b$.

Braithwaite, R. J., and O. B. Olesen, Ice ablation in west Greenland in relation to air temperature and global radiation, Z. Gletscherkd. Glazialgeol., 20, 155-160, 1984.

Brecher, H. H., Surface velocity determination on large polar glaciers by aerial photogrammetry, Ann. Glaciol., 8, 22-26, 1986.

Brenner, A. C., R. A. Bindschadler, R. H. Thomas, and H. J. Zwally, Slope-induced errors in radar altimetry over continental ice sheets, J. Geophys. Res., 88, 1617-1623, 1983.

Bromwich, D. H., Snowfall in high southem lattitudes, Rev. Geophys., 26, 149-168, 1988.

Budd, W. F., and I. N. Smith, The state of balance of the Antarctic Ice Sheet: An updated assessment 1984, Glaciers, Ice Sheets, and Sea Level: Effect of a $\mathrm{CO}_{2}$-Induced Climatic Change, Rep. DOE/EV/60235-1, pp. 172-177, U.S. Dep. of Energy, Washington, D. C., 1985.

Budd, W. F., I. Landon Smith, and E. Wishart, The Amery Ice Shelf, in Physics of Snow and Ice, vol. I, part 1, pp. 447-467, edited by H. Oura, Institute of Low Temperature Science, Hokkaido University, Sapporo, Japan, 1967.

Bull, C., Snow accumulation in Antarctica, in Research in the Antarctic, edited by L. O. Quam, pp. 367-321, American Association for the Advancement of Science, Washington, D. C., 1971.

Cameron, R. L., Glaciological studies at Wilkes Station, Budd Coast, Antarctica, in, Antarctic Snow and Ice Studies, Antarct. Res. Ser., vol. 2, pp. 1-36, edited by M. Mellor, AGU, Washington, D. C., 1964.

Comiso, J. C., H. J. Zwally, and J. L. Saba, Radiative transfer modeling of microwave emission and dependence on fim properties, Ann. Glaciol., 3, 54-58, 1982. 
Doake, C. S. M., Antarctic mass balance: Glaciological evidence from Antarctic Peninsula and Weddell Sea sector, Glaciers, Ice Sheets, and Sea Level: Effect of a $\mathrm{CO}_{2}$-Induced Climatic Change, Rep. DOE/EV/60235-1, pp. 197-209, U.S. Dep. of Energy, Washington, D. C., 1985

Finsterwalder, R., Measurement of glacier variations in the eastem Alps, particularly in the Gurgl area, IAHS Publ., 58, 7-15, 1962.

Giovinetto, M. B., and C. R. Bentley, Surface balance in ice drainage systems of Antarctica, Antarct. J. U.S., 20, 6-13, 1985.

Giovinetto, M. B., and J. H. Zumberge, The ice regime of the eastem part of the Ross Ice Shelf drainage system, IAHS Publ., 79, 255-266, 1967.

Giovinetto, M. B., E. S. Robinson, and C. W. M. Swithinbank, The regime of the western part of the Ross Ice Shelf drainage system, J. Glaciol., 6, 55-68, 1966.

Grove, J. M., The Little Ice Age, 498 pp., Methuen, London, 1988.

Gundestrup, N. S., R. A. Bindschadler, and H. J. Zwally, SEASAT range measurements verified on a 3-D ice sheet, Ann. Glaciol., 8, 69-72, 1986.

Haeberli, W., P. Müller, P. Alean, and H. Bösch, Glacier changes following the Little Ice Age-A survey of the intemational data basis and its perspectives, in Glacier Fluctuations and Climatic Change, edited by J. Oerlemans, pp. 77-101, Kluwer, Dordrecht, Netherlands, 1989.

Hoinkes, H., Zur Bestimmung der Jahresgrenzen in mehrjährigne Schneeansammlungen, Arch. Meteorol. Geophys. Bioklimatol., Ser. B, 8, 56-60, 1957.

Hoinkes, H., Methoden und Möglichkeiten von Massenhaushalt studien auf Gletschem, Z. Gletscherkd. Glazialgeol., 6, $37-90,1970$.

Hoinkes, H., and R. Rudolph, Mass balance studies on the Hintereisfemer, Oetztal Alps, 1952-1961, J. Glaciol., 4, 266-280, 1962.

Hutter, K., Theoretical Glaciology, 510 pp., D. Reidel, Norwood, Mass., 1983.

Huybrechts, $\mathrm{Ph}$., and J. Oerlemans, Thermal regime of the East Antarctic ice sheet: A numerical study on the role of the dissipation-strain rate feedback with changing climate, $A n n$. Glaciol., 11, 52-59, 1989.

Huybrechts, Ph., P. de Nooze, and H. Decleir, Numerical modelling of Glacier d'Argentiere and its historic front variations, in Glacier Fluctuations and Climatic Change, edited by J. Oerlemans, pp. 373-379, Kluwer Academic, Boston, Mass., 1989.

Jaeger, J., Developing policies for responding to climate change, report, World Meteorol. Org. and U. N. Environ. Programme, Geneva, 1988.

Jezek, K. C., D. J. Cavalieri, and A. Hogan, Antarctic Ice Sheet brightness temperature variations, in Sea Ice Properties and Processes, Proceedings of the W. F. Weeks Symposium, CRREL Monogr. 90-1, edited by S. F. Ackley pp. 217-223, U.S. Cold Regions Research and Engineering Lab, Hanover, N. H., 1990.

Jouzel, J., C. Lorius, J. R. Petit, C. Genthon, N. I. Barkov, V. M. Kotlyakov, and V. M. Petrov, Vostok ice core: A continuous isotope temperature record over the last climatic cycle (160,000 years), Nature, 329, 403-408, 1987.

Kosack, H. P., Zur frage des Wasserhaushalts in der Antarktis. Polarforschung, 1/2, 286-294, 1956.

Kostecka, J. M., and I. M. Whillans, Mass balance along two transects of the west side of the Greenland Ice Sheet, $J$. Glaciol., 34, 31-39, 1988.

Kotlyakov, V. M., The intensity of nourishment of the Antarctic Ice Sheet, IAHS Publ., 58, 100-110, 1962.
Krimmel, R. M., and M. F. Meier, Glacier applications of ERTS images, J. Glaciol., 15, 391-402, 1975.

LaChapelle, E., Errors in ablation measurements from settlement and sub-surface melting, J. Glaciol., 3, 458-467, 1959.

Lingle, C. S., A. C. Brenner, and J. J. Zwally, Satellite altimetry, semivariograms, and seasonal elevation changes in the ablation zone of west Greenland, Ann. Glaciol., 14, 158-163, 1990.

Lister, H., Geophysical investigations of the Commonwealth Trans-Antarctic expedition, Geogr. J. 125, 343-351, 1959.

Loewe, F., Höhenverhältnisse und Masseshaushalt des grönländischen Indlandeises, Gerlands Beitr. Geophys., 48, 1936.

Loewe, F., Etudes de glaciologie en Terre Adélie, 1951-1952. Exped. Polaires Fr. Result. Sci., 9, 159 pp., 1956.

Loewe, F., The water budget in Antarctica, Proc. Symp. Pac. Antarct. Sci., 1, 101-110, 1967.

Lorius, C., Contribution to the knowledge of the Antarctic Ice Sheet: A synthesis of glaciological measurements in Terre Adélie, J. Glaciol., 4, 79-92, 1962.

Lucchita, B. K., and H. M. Ferguson, Antarctica: Measuring glacier velocity from satellite images, Science, 234, 1105-1108, 1986.

MacAyeal, D. R., R. A. Bindschadler, S. Shabtaie, S. Stephensen, and C. R. Bentley, Force, mass, and energy budgets of the Crary Ice Rise complex, Antarctica, J. Glaciol., 33, 218-230, 1987. (Correction, J. Glaciol., 35, 151-152, 1989.)

Manabe, S., and R. J. Stouffer, Sensitivity of a global climate model to an increase of $\mathrm{CO}_{2}$ concentration in the atmosphere, J. Geophys. Res., 85, 5529-5554, 1980.

Martin, T. V., H. J. Zwally, A. C. Brenner, and R. A. Bindschadler, Analysis and retracking of continental ice sheet radar altimeter waveforms, J. Geophys. Res., 88, 1608-1616, 1983.

McDonald, J., and I. M. Whillans, Comparison of results from transit satellite tracking, Ann. Glaciol., 11, 83-88, 1988.

Meier, M. F., Snow and ice in a changing hydrological world, Hydrol. Sci. J., 28, 3-22, 1983.

Meier, M. F., Contribution of small glaciers to global sea level, Science, 226, 1418-1421, 1984.

Meier, M. F., Mass balance of the glaciers and small ice caps of the world, Glaciers, Ice Sheets, and Sea Level: Effect of a $\mathrm{CO}_{2}$-Induced Climatic Change, Rep. DOE/EVI60235-1, pp. 139-144, U.S. Dep. of Energy, Washington, D. C., 1985.

Mellor, M., Photogrammetric flow measurements on Antarctic glaciers (abstract), Eos Trans. AGU, 39, 1158, 1958.

Mellor, M., Mass balance studies in Antarctica, J. Glaciol., 3, 522-533, 1959.

Mellor, M., The Greenland mass balance flux divergence considerations, IAHS Publ., 79, 275-281, 1968.

Mercer, J. H., West Antarctic ice sheet and $\mathrm{CO}_{2}$ greenhouse effect: A threat of disaster, Nature, 271, 321-325, 1978.

Morgan, P. J., A photogrammetric survey of Hoseason Glacier, Kemp Coast, Antarctica, J. Glaciol., 12, 113-120, 1973.

Morgan, V. I., and T. H. Jacka, Mass balance studies in East Antarctica, IAHS Publ., 131, 253-260, 1981.

Müller, F., and C. M. Keeler, Errors in short-term ablation measurements on melting ice surfaces, J. Glaciol., 8, 91-105, 1969.

Naruse, R., Thinning of the ice sheet in Mizuho Plateau, East Antarctica, J. Glaciol., 24, 45-52, 1979.

Nye, J. F., Correspondence: Errors in the determination of ablation using stakes: Comments on Dr. Vallon's letter, $J$. Glaciol., 7, 133, 1968.

Oerlemans, J., Glaciers as indicators of a carbon dioxide warming, Nature, 320, 607-609, $1986 a$.

Oerlemans, J., An attempt to simulate historic front variations of Nigardsbreen, Norway, Theor. Appl. Clim., 37, 126-135, $1986 b$. 
Oerlemans, J., Simulation of historic glacier variations with a simple climate-glacier model, J. Glaciol., 34, 333-341, 1988.

Oerlemans, J., A projection of future sea level, Clim. Change, 15, 151-174, 1989.

Oerlemans, J., and C. J. van der Veen, Ice Sheets and Climate, 217 pp., D. Reidel, Norwood, Mass., 1984.

Orombelli, G., and S. C. Porter, Late Holocene fluctuations of Brenva Glacier, Geogr. Fis. Din. Quat., 5, 14-37, 1982.

Parkinson, C. L., J. C. Comiso, H. J. Zwally, D. J. Cavalieri, P. Gloersen, and W. J. Campbell, Arctic sea ice 1973-1976: Satellite passive-microwave observations, NASA Spec. Publ., SP-489, 196 pp., 1987.

Partington, K. C., W. Cudlip, N. F. McIntyre, and S. King-Hele, Mapping of Amery Ice Shelf, Antarctica, surface features by satellite altimetry, Ann. Glaciol., 9, 183-188, 1987.

Porter, S. C., Glaciological evidence of Holocene climatic change, in Climate and History, edited by T. M. L. Wigley, M. J. Ingram, and G. Farmer, pp. 82-110, Cambridge University Press, New York, 1981.

Porter, S. C., Pattem of forcing of Northem Hemisphere glacier variations during the last millenium, Quat. Res., 26, 27-48, 1986.

Reeh, N., Greenland ice-sheet mass balance and sea-level change, Glaciers, Ice Sheets, and Sea Level: Effect of a $\mathrm{CO}_{2}$-Induced Climatic Change, Rep. DOE/EV/60235-1, pp. 155-171, U.S. Dep. of Energy, Washington, D. C., 1985.

Reeh, N., and N. S. Gundestrup, Mass balance of the Greenland ice sheet at Dye 3, J. Glaciol., 31, 198-200, 1985.

Reeh, N., H. B. Clausen, W. Dansgaard, N. Gundestrup, C. U. Hammer, and S. J. Johnsen, Secular trends of accumulation rates at three Greenland stations, J. Glaciol., 20, 27-30, 1978.

Reeh, N., S. J. Johnsen, and D. Dahl-Jensen, Dating the Dye 3 deep ice core by flow model calculations, in Greenland Ice Core: Geophysics, Geochemistry and the Environment, Geophys. Monogr. Ser., vol. 33, edited by C. C. Langway, H. Oeschger, and W. Dansgaard, pp. 57-65, AGU, Washington, D. C., 1985.

Ridley, J. K., and K. C. Partington, A model of satellite radar altimeter return from ice sheets, Int. J. Remote Sens., 9, 601-624, 1988.

Rubin, M. J., The atmospheric advection and the Antarctic mass and heat budget, in Antarctic Research, AGU Publ. 1036, edited by $H$. Wexler, M. J. Rubin, and J. E. Caskey, pp. 149-159, AGU, Washington, D. C., 1962.

Schlesinger, M. E., Atmospheric general circulation model simulations of the modem Antarctic climate, in Environment of West Antarctica: Potential $\mathrm{CO}_{2}$-Induced Changes, pp. 155-196, National Academy Press, Washington, D. C., 1984.

Seckel, H., Das geometrische Nivellement über das grönländische Inlandeis der Gruppe Nivellement A der Internationalen Glaziologischen Grönland Expedition 1967-68, Medd. Grфnl., 187(3), 86 pp., 1977.

Shabtaie, S., and C. R. Bentley, West Antarctic ice streams draining into the Ross Ice Shelf: Configuration and mass balance, J. Geophys. Res., 92, 1311-1336, 1987.

Shabtaie, S., I. M. Whillans, and C. R. Bentley, The morphology of ice streams A, B and C, West Antarctica, and their environs, J. Geophys. Res., 92, 8865-8883, 1987.

Shabtaie, S., C. R. Bentley, R. A. Bindschadler, and D. R. MacAyeal, Mass-balance studies of ice streams A, B, and C, West Antarctica, and possible surging behavior of ice stream B, Ann. Glaciol., 11, 137-149, 1988.

Shimizu, H., O. Watanabe, S. Kobayashi, T. Yamada, R. Naruse, and Y. Ageta, Glaciological aspects and mass budget of the ice sheet in Mizuho Plateau, in Glaciological studies in Mizuho Plateau, East Antarctica, 1969-1975, Mem. Natl. Inst. Polar Res. Spec. Issue, 7, edited by T. Ishida, pp. 264-274, National Institute of Polar Research, Tokyo, 1978.
Smith, J. N., and W. F. Budd, The derivation of past climate changes from observed changes of glaciers, IAHS Publ., 131, 31-52, 1981 .

Stiles, W. H., and F. T. Ulaby, The active and passive microwave response to snow parameters, 1, Wetness, J. Geophys. Res., $85,1037-1044,1980$.

Stroeven, A., R. van der Wal, and J. Oerlemans, Historic front variations of the Rhone Glacier. Simulation with an ice flow model, in Glacier fluctuations and climatic change, edited by J. Oerlemans, pp. 391-405, Kluwer Academic, Boston, Mass., 1989.

Swift, C. T., and D. J. Cavalieri, Passive microwave remote sensing for sea ice research, Eos Trans. AGU, 66, 1210-1212, 1985.

Swithinbank, C., Satellite photographs of the Antarctic Peninsula Area, Polar Rec. 15, 19-24, 1970.

Vallon, M., Correspondence: Errors in the determination of ablation using stakes, J. Glaciol., 7, 132-133, 1968.

Van der Veen, C. J., and I. M. Whillans, Flow laws for glacier ice: Comparison of numerical predictions and field measurements, J. Glaciol., 36, 324-339, 1990.

Weidick, A., Observations of some holocene glacier fluctuations in west Greenland, Medd. Grфnl. 165(6), 202 pp., 1968.

Weidick, A., Review of glacier changes in west Greenland, Z. Gletscherkd. Glazialgeol., 21.301-309, 1985.

Wexler, H., Correspondence with M. Mellor on Antarctic geophysics, Tellus, 10, 498-499, 1958.

Wexler, H., Ice budgets for Antarctic and changes in sea-level, $J$. Glaciol., 3, 866-872, 1961.

Whillans, I. M., State of equilibrium of the West Antarctic ice sheet, Science, 182, 476-479, 1973.

Whillans, I. M., Radio-echo layers and the recent stability of the West Antarctic ice sheet, Nature, 264, 152-155, 1976.

Whillans, I. M., The equation of continuity and its application to the ice sheet near "Byrd" Station, Antarctica, J. Glaciol., 18 359-371, 1977.

Whillans, I. M., Reaction of the accumulation zone portions of glaciers to climatic change, J. Geophys. Res., 86, 4274-4282, 1981.

Whillans, I. M., and R. A. Bindschadler, Mass balance of ice stream B, West Antarctica, Ann. Glaciol., 11, 187-193, 1988.

Whillans, I. M., and J. F. Bolzan, A method for computing shallow ice-core depths, J. Glaciol., 34, 355-357, 1988.

Wood, F. B., Global alpine glacier trends, 1960 s to 1980 s, Arctic Alpine Res., 20, 404-413, 1988.

Zwally, H. J., Microwave emissivity and accumulation rate of polar fim, J. Glaciol., 18, 195-215, 1977.

Zwally, H. J., Observing polar-ice variability, Ann. Glaciol., 5, 191-198, 1984.

Zwally, H. J., Growth of Greenland ice sheet: Interpretation, Science, 246 1589-1591, 1989.

Zwally, H. J., and J.E. Walsh, Comparison of observed and modeled ice motion in the Arctic Ocean, Ann. Glaciol., 9, 229-235, 1987.

Zwally, J. J., R. A. Bindschadler, A. C. Brenner, T. V. Martin, and R. H. Thomas, Surface elevation contours of Greenland and Antarctic ice sheets, J. Geophys. Res., 88, 1589-1596, 1983.

Zwally, J. H., S. N. Stephenson, R. A. Bindschadler, and R. H. Thomas, Antarctic ice-shelf boundaries and elevations from satellite radar altimetry, Ann. Glaciol., 9, 229-235, 1987.

Zwally, H. J., A. C. Brenner, J. A. Major, R. A. Bindschadler, and J. G. Marsh, Growth of Greenland ice sheet: Measurement, Science, 246, 1587-1589, 1989.

C. J. van der Veen, Byrd Polar Research Center, Ohio State University, Columbus, $\mathrm{OH} 43210$. 